Commodity Price Shocks and the Business Cycle: Structural Evidence for the U.S.

Matthias Gubler and Matthias S. Hertweck

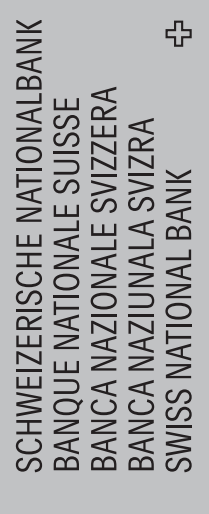

น

(a)

(4)

$\frac{8}{10}$

م.

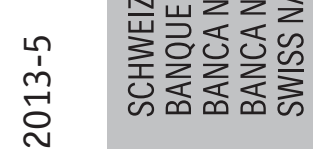

$\frac{0}{2}$ 
The views expressed in this paper are those of the author(s) and do not necessarily represent those of the Swiss National Bank. Working Papers describe research in progress. Their aim is to elicit comments and to further debate.

\section{Copyright ${ }^{\odot}$}

The Swiss National Bank (SNB) respects all third-party rights, in particular rights relating to works protected by copyright (information or data, wordings and depictions, to the extent that these are of an individual character). SNB publications containing a reference to a copyright ( $\odot$ Swiss National Bank/SNB, Zurich/year, or similar) may, under copyright law, only be used (reproduced, used via the internet, etc.) for non-commercial purposes and provided that the source is mentioned. Their use for commercial purposes is only permitted with the prior express consent of the SNB.

General information and data published without reference to a copyright may be used without mentioning the source.

To the extent that the information and data clearly derive from outside sources, the users of such information and data are obliged to respect any existing copyrights and to obtain the right of use from the relevant outside source themselves.

\section{Limitation of liability}

The SNB accepts no responsibility for any information it provides. Under no circumstances will it accept any liability for losses or damage which may result from the use of such information. This limitation of liability applies, in particular, to the topicality, accuracy, validity and availability of the information.

ISSN 1660-7716 (printed version)

ISSN 1660-7724 (online version)

๑ 2013 by Swiss National Bank, Börsenstrasse 15, P.0. Box, CH-8022 Zurich 


\title{
Commodity Price Shocks and the Business Cycle: Structural Evidence for the U.S.*
}

\author{
Matthias Gubler ${ }^{\dagger}$ \\ Swiss National Bank
}

\author{
Matthias S. Hertweck \\ University of Konstanz
}

This Version: April 25, 2013

\begin{abstract}
This paper evaluates the relative importance of commodity price shocks in the U.S. business cycle. Therefore, we extend the standard set of business cycle shocks to include unexpected changes in commodity prices. The resulting SVAR shows that commodity price shocks are a very important driving force of macroeconomic fluctuations - second only to investment-specific technology shocks — particularly with respect to inflation. Neutral technology shocks and monetary policy shocks, on the other hand, seem less relevant at business cycle frequencies. Neutral technology shocks rather play an important role at low frequencies.
\end{abstract}

JEL Classifications: C32, E32, E52, Q43

Keywords: business cycles, commodity price shocks, structural VAR

*This paper is based on Chapter 2 of the first author's doctoral dissertation written at the University of Basel. Without implication, we would like to thank Ralf Brüggemann, Patrick Bunk, Jesús Fernández-Villaverde, Christian Glocker, Christian Kascha, Robert G. King, Marco Lombardi, Alexander Perruchoud, Fabien Rondeau, Almuth Scholl, Frank Schorfheide, Atılım Seymen, Konstantinos Theodoridis, Sebastian Watzka, Attilio Zanetti, and an anonymous referee, as well as conference participants at DIW Berlin, RGS Dortmund, ifo Dresden, VfS Frankfurt, IWH-CIREQ Halle, ICMAIF Rethymno, CEF San Francisco, SOLE Vancouver, and seminar audiences at the Bank of England, Essex, JLU Gießen, LMU Munich, Penn, and Zurich (KOF-ETH-UZH) for extensive comments and suggestions; and Riccardo DiCecio for kindly sharing his data. Hermione Miller-Moser provided excellent editorial assistance. The first author is indebted to Peter Kugler for his help and supervision. Part of this research project was conducted while the second author was affiliated with the University of Basel, supported by the Swiss National Science Foundation (Project No. 118306). The views expressed in this paper do not necessarily reflect the view of the Swiss National Bank.

†Contact Address: Swiss National Bank, Börsenstrasse 15, P.O. Box, 8022 Zürich, Switzerland. Email: matthias.gubler@snb.ch

$\ddagger$ Corresponding Author: University of Konstanz, Department of Economics, Box 145, 78457 Konstanz, Germany.

Email: matthias.hertweck@uni - konstanz.de, Homepage: http : //www.hertweck.org/ 


\section{Introduction}

What are the sources of the U.S. business cycle? In recent years, the main body of business cycle research has focused on the impact of (neutral) technology shocks (Galí 1999), investment-specific technology shocks (Fisher 2006), and monetary policy shocks (Christiano et al. 1996). Following this strand of the literature, technology shocks, particularly investment-specific technology shocks, are considered to be a very important driving force of the business cycle. ${ }^{1}$ On the other hand, Hamilton (2008) emphasizes that "nine out of ten" recessions in the postwar era are associated with a surge in oil prices. Given that oil is both a consumption good and an intermediate good, such a surge has a direct impact on the price level and changes the cost structure of firms (Medina \& Soto 2005). Quite surprisingly, however, the macroeconomic effects of oil/commodity price shocks have been studied either in isolation (Edelstein \& Kilian 2007, 2009, Blanchard \& Galí 2010), or together with monetary policy shocks (Bernanke et al. 1997, Hamilton \& Herrera 2004, Herrera \& Pesavento 2009, Kilian \& Lewis 2011), but never so far in conjunction with the standard set of business cycle shocks.

This paper bridges the gap between these two strands of the literature. Our main aim is to quantify the relative importance of commodity price shocks in the U.S. business cycle. Therefore, we develop a nine-dimensional SVAR, where the standard set of business cycle shocks (Altig et al. 2011) is extended to include unexpected changes in commodity prices. $^{2}$ The commodity price shock is identified by assuming that commodity prices are predetermined with respect to U.S. macroeconomic aggregates. This short-run restriction is based on the observation that energy prices do not respond immediately to macroeconomic news (Kilian \& Vega 2011). As explained by Kilian (2008, p. 4), this assumption provides a "good approximation" when working with quarterly data. Furthermore, following Edelstein \& Kilian (2007, 2009), we focus our analysis on the average effects of commodity price shocks, irrespective of whether these movements are driven by changes in supply or demand. We subject these identifying assumptions to a number of robustness checks (see below).

We find that that commodity price shocks are a very important driving force of the U.S. business cycle, second only to investment-specific technology shocks. In particular, we show that commodity price shocks explain a large share of cyclical movements in inflation. Results from a historical decomposition of shocks indicate that commodity price shocks have played a significant role especially during and after the the first OPEC oil crisis. Unexpected variations in the relative price of investment goods are the pri-

\footnotetext{
${ }^{1}$ Evidence supporting this view includes SVAR studies (Ravn \& Simonelli 2008, Canova et al. 2010, Altig et al. 2011) and estimated DSGE models (Gertler et al. 2008, Justiniano et al. 2010).

${ }^{2}$ We measure commodity prices using the index by the BLS (2012, see also Section 2.1). Given that this broad commodity price index is less prone to changes in institutional settings than the price of crude oil (see Figure 1), we are able to estimate the 9-dimensional SVAR model based on a long sample period.
} 
mary determinant of business cycle fluctuations in output and per-capita hours. Neutral technology shocks and monetary policy shocks, on the other hand, seem less relevant at business cycle frequencies. Neutral technology shocks rather play an important role at low frequencies.

Furthermore, we demonstrate that an unexpected increase in commodity prices is characterized by significant U-shaped responses in output, consumption and per-capita hours. Most notably, the inflation rate displays a significant spike, followed by a rapid return to the initial level. The unexpected surge in the inflation rate prompts the Federal Reserve to elevate the nominal interest rate. Results of a counterfactual exercise indicate that the systematic contractionary response helped the Federal Reserve to achieve price stability in the long run, yet at the cost of a significant economic downturn in output and per-capita hours. ${ }^{3}$

Besides, we find that the estimated impulse response functions to monetary policy shocks, neutral technology shocks, and investment-specific technology shocks are very similar compared to those obtained by Altig et al. (2011) or Ravn \& Simonelli (2008). In particular, the response of per-capita hours to neutral technology shocks is positive and marginally significant. This result is very robust, no matter whether the data are filtered or not, indicating that concerns about leaving (Fernald 2007, Francis \& Ramey 2009, Canova et al. 2010) or removing (Gospodinov et al. 2011) low-frequency movements in the data are quantitatively not very important as long as the size of the information set is sufficiency large. On the other hand, if the information set is small, the impact response of per-capita hours is indeed extremely sensitive to the treatment of the data. This result, confirms our choice to estimate a large-scale SVAR.

We perform the following robustness checks to test the sensitivity of our results. First, we relax the contemporaneous exogeneity assumption by allowing for immediate responses in the commodity price index to innovations in U.S. aggregate activity; i.e., labor productivity growth and per-capita hours. Second, in order to control for contemporaneous movements in the global demand for commodities, we include a global demand indicator, which is ordered first before the commodity price index (as in Kilian \& Lewis 2011). Furthermore, we examine robustness to the specific commodity price index used, the choice of the lag length, and the sub-sample properties of our model. We find that the effects of a commodity price shock on output and the inflation rate are milder in the post-Volcker period, but the impulse responses remain statistically significant at the $10 \%$ level. This result is consistent with previous estimates by Edelstein \& Kilian (2009), Herrera \& Pesavento (2009) or Blanchard \& Galí (2010).

\footnotetext{
${ }^{3}$ The counterfactual exercise presumes that the Federal Funds rate is kept constant when the U.S. economy is hit by a commodity price shock (as in Bernanke et al. 1997). However, our approach differs in many aspects from theirs as we adopt several suggestions - e.g. a linear VAR model (Kilian \& Vigfusson 2011) with a lag length beyond one year (Hamilton \& Herrera 2004) — made in the subsequent debate.
} 
The remainder of this paper is organized as follows. Section (2) presents the identification and estimation strategies. Section (3) presents the results. Section (4) performs several robustness checks. Section (5) concludes.

\section{Identification and Estimation Strategy}

This paper evaluates the relative importance of commodity price shocks in the U.S. business cycle. Therefore, we extend the standard set of business cycle shocks (i.e., monetary policy, neutral technology, and investment-specific technology Altig et al. 2011) to include unexpected changes in commodity prices.

\section{$2.1 \quad$ Data}

We develop a nine-dimensional VAR in order to capture the impact of the relevant factors for macroeconomic fluctuations. The sample period covers aggregate U.S. data between 1955Q3 and 2007Q4. ${ }^{4}$ The following variables enter the SVAR: growth in the relative price of investment goods $\Delta q_{t}$, growth in labor productivity $\Delta a_{t}$ (measured by the ratio of real output to hours per capita in the business sector), the CPI inflation rate $\pi_{t}$, hours per capita $h_{t}$, the consumption share in output $c_{t}$, the investment share in output $i_{t}$, the employment rate $n_{t}$, the Federal Funds rate $r_{t}$, and the commodity price index "PPI: crude materials for further processing" $p_{t}$ (see also Figure 1). We prefer to use this particular commodity price index by the BLS (2012, p. 8) - also used by Hanson (2004) or Sims \& Zha (2006) - as it appropriately captures the time-varying importance of different raw materials, based on input-output studies by the BEA. ${ }^{5}$ In addition, Figure (1) shows that, compared with the price of crude oil in the pre-1973 period, the pattern of changes in the broad commodity price index is much less discrete. All time series are seasonally adjusted (where applicable). Precise definitions can be found in the Appendix (Tables 1 and 2).

Note that our information set explicitly considers the consumption and the investment share in output. As demonstrated by Christiano et al. (2003), omitting these two variables may be associated with a serious specification error. This effect is likely due to the fact

\footnotetext{
${ }^{4}$ The endpoint of our sample marks the start of the Great Recession when the Federal Reserve adopted several unconventional monetary policy measures, which are unlikely to be appropriately captured by our identification procedure.

${ }^{5}$ In contrast, the Commodity Research Bureau (2013) BLS Spot Index (available from 1951Q1) does not capture petroleum based products. The Continuous Commodity Index by Thomson Reuters (2013, calculated backwards until 1956Q4); i.e., the "old CRB", captures petroleum based products, but continuously rebalances the different commodity categories to maintain an equal and time-invariant weight (we use this index for robustness checks presented in Section 4.3 and Figure 18). The "new" Thomson Reuters/Jefferies (2013) CRB Index, introduced in 2005, captures petroleum based products and uses time-varying weights, but was calculated backwards only until 1994Q1 (see the link in the references). Figure (1) shows that the BLS (2012) index and the "new" Thomson Reuters/Jefferies (2013) CRB index behave remarkably similar in the overlapping sample.
} 
that these two variables reflect "news that agents see but we do not" (Cochrane 1994, p. 295). In addition, we include the employment rate in order to analyze labor adjustment along the extensive and the intensive margin.

Recently, Fernald (2007) has shown that SVAR models with long-run restrictions may be biased by "low-frequency movements" in hours per capita. This effect can be attributed to sectoral changes involving government and non-profit employment or the movement of the baby boom generation through the labor market (Francis \& Ramey 2009). Differencing removes the low-frequency movements from the data. However, differencing a bounded series (like per-capita hours) may involve misspecification issues (Hamilton 1994, p. 652). Therefore, Canova et al. (2010) suggest to filter the data prior to estimation. On the other hand, Gospodinov et al. (2011) argues that filtering the data prior to estimation removes information necessary to identify these shocks using long-run restrictions.

With this in mind, we estimate our SVAR model in two specifications; i.e., the "level specification" and the "bandpass filter specification". For the reader's convenience, we offer comparisons between these two specifications throughout the paper. For the former, we first take the natural logarithm of all variables except for the (net) Federal Funds rate, and then difference labor productivity and the relative price of investment goods. For the latter, we additionally apply a one-sided bandpass filter (Christiano \& Fitzgerald $2003)^{6}$ in order to control for low-frequency movements in per-capita hours. We prefer this particular filter since agents know only the past (Lucas 1980). More precisely, we apply the one-sided bandpass filter not only to per-capita hours, but to all series considered. ${ }^{7}$ Figure (2) illustrates that this procedure allows us to maintain spectral coherence (Granger 1969) between labor productivity growth and per-capita hours. When all series are filtered — as in the top panel — we are able to break the low-frequency comovement and minimize distortions at higher (particularly, at business cycle) frequencies. When only per-capita hours are filtered — as in the bottom panel — we are less successful in breaking the low-frequency comovement and distort the relationship at business cycle frequencies.

\section{$2.2 \quad$ Identification}

We estimate the following four structural shocks using standard identifying assumptions. Commodity price shocks (Rotemberg \& Woodford 1996) and monetary policy shocks (Christiano et al. 1996) are identified using short-run restrictions. Neutral and investment-

\footnotetext{
${ }^{6}$ To be precise, we first remove the drift of the series and then apply the one-sided bandpass filter with following options: $p_{l}=2, p_{u}=52$, root $=1$, drift $=0$, ifilt $=0$, nfix $=-1$, thet $=1$. Where available, we use data from 1948Q1 to 2007Q4 and then drop the filtered data points prior to 1955Q3. The Federal Funds rate is only available from 1954Q3.

${ }^{7}$ Our long-run identification strategy (see Section 2.2) requires that labor productivity and the relative price of investment goods enter the SVAR in first differences. Hence, we difference these variables first and then apply the bandpass filter.
} 
specific technology shocks are identified using long-run restrictions (Galí 1999, Fisher 2006). ${ }^{8}$ The remaining shocks in the nine-dimensional SVAR model are identified via a recursive ordering scheme.

Consequently, the reduced-form VAR is given by:

$$
\begin{aligned}
x_{t} & =a+B(L) x_{t-1}+e_{t} \\
x_{t} & =\left[\begin{array}{lllll}
\Delta q_{t} & \Delta a_{t} & z_{t} & r_{t} & p_{t}
\end{array}\right]^{\prime} \\
z_{t} & =\left[\begin{array}{lllll}
\pi_{t} & h_{t} & c_{t} & i_{t} & n_{t}
\end{array}\right]^{\prime}
\end{aligned}
$$

where $B(L)$ is a lag polynomial of order $M$. By premultiplying with $\beta_{0}$, we obtain the structural VAR:

$$
\beta_{0} x_{t}=\alpha+\beta(L) x_{t-1}+\epsilon_{t}
$$

where $\epsilon_{t}$ denotes the vector of fundamental shocks. The orthogonality assumption implies that its covariance matrix $V_{\epsilon}=E\left(\epsilon_{t}^{\prime} \epsilon_{t}\right)$ is diagonal. Moreover, we normalize the diagonal of $\beta_{0}$ to a $9 \mathrm{x} 1$ vector of ones.

Both technology shocks are identified using long-run restrictions (Shapiro \& Watson 1988, Blanchard \& Quah 1989). Following Fisher (2006), we assume that only investmentspecific technology shocks affect the relative price of investment goods in the long run. The long-run level of aggregate productivity may be affected by both investment-specific and neutral technology shocks. No other shock has any long-run effect on the relative price of investment goods or the level of labor productivity (Galí 1999).

The identification strategies of the commodity price shock and the monetary policy shock are based on short-run restrictions. We impose the constraint that no other variable may respond contemporaneously when the Fed's monetary policy — given by the Federal Funds rate - deviates from its linear rule. This presumes that, when setting the nominal interest rate, the Fed's information set includes the contemporaneous values of all other variables included in the SVAR (Christiano et al. 1996). Moreover, we identify the commodity price shock by assuming that nominal commodity prices are predetermined with respect to U.S. macroeconomic aggregates. ${ }^{9}$ This identification strategy was originally developed by Rotemberg \& Woodford (1996) in the context of nominal oil price shocks. ${ }^{10}$ The assumption of predeterminedness is based on the observation that energy prices do not respond contemporaneously to macroeconomic news (Kilian \& Vega 2011). As ex-

\footnotetext{
${ }^{8}$ The current section follows largely the identification procedure described in Ravn \& Simonelli (2008), with commodity prices instead of government spending. We are unable to find significant movement to government spending shocks when we include government spending per capita instead of commodity prices in our SVAR model

${ }^{9}$ In contrast, innovations in real commodity prices may be due to unexpected changes in U.S. inflation and, therefore, should be treated as endogenous (Rotemberg \& Woodford 1996, Hamilton 2008). See Kilian \& Lewis (2011) for a recent work on this issue.

${ }^{10}$ The shape of the impulse responses remains unchanged when we use the West Texas Intermediate spot oil price instead, but the broad commodity price index turns out to be quantitatively more important.
} 
plained by Kilian (2008, p. 4), this short-run restriction provides a "good approximation" when working with quarterly data. ${ }^{11}$ Nevertheless, when applying this approach to commodity prices, we take into account the possibility that the broad commodity price index may behave less sluggishly than the nominal oil price (Alquist et al. 2011). Moreover, following Edelstein \& Kilian (2007, 2009), we focus our analysis on the average effects of commodity price shocks, irrespective of whether these movements are driven by changes in supply or demand (see Kilian 2009, for a detailed discussion of this topic). We subject these identifying assumptions to the following robustness checks. Therefore, Section (4.1) relaxes the contemporaneous exogeneity assumption to allow for immediate responses in the commodity price index to innovations in U.S. aggregate activity; i.e., labor productivity growth and per-capita hours. Section (4.2) includes a global demand indicator which is ordered first before the commodity price index (as in Kilian \& Lewis 2011) — in order to control for contemporaneous movements in the global demand for commodities. ${ }^{12}$ Besides, note that our linear VAR model presumes that commodity price increases and decreases have symmetric effects (Kilian \& Vigfusson 2011).

Consequently, the process for the Federal Funds rate depends on the current and past values of all other variables, but no other process depends on its current realizations. This implies that the second-last column of the contemporaneous coefficient matrix $\beta_{0}$ consists of zeros, apart from the second-last element which is normalized to unity. The process for the commodity price, on the other hand, depends on the lagged values of commodity prices and all other variables, but not on the current realizations of any other variable. Hence, the last row of $\beta_{0}$ consists of zeros, apart from the last element which is normalized to unity. Furthermore, the order of the variables included in the vector $z_{t}$ imposes a number of additional short-run restrictions on $\beta_{0}$.

\subsection{Estimation}

The first equation of the structural VAR (equation 2):

$$
p_{t}=\alpha^{p}+\sum_{j=1}^{M} \beta_{x, j}^{p} x_{t-j}+\epsilon_{t}^{p}
$$

\footnotetext{
${ }^{11}$ Applications of this identification strategy to quarterly data include Rotemberg \& Woodford (1996), Edelstein \& Kilian (2007), and Blanchard \& Galí (2010).

${ }^{12}$ Note that, given that commodity prices are denominated in U.S. dollars, we are not able to identify endogenous (real) exchange rate driven commodity price movements.
} 
identifies the commodity price shock $\epsilon_{t}^{p}$. We estimate equation (3) using ordinary least squares. The second equation of the SVAR:

$$
\begin{aligned}
\Delta q_{t}=\alpha^{q} & +\sum_{j=1}^{M} \beta_{q, j}^{q} \Delta q_{t-j}+\sum_{j=0}^{M-1} \beta_{a, j}^{q} \Delta^{2} a_{t-j} \\
& +\sum_{j=0}^{M-1} \beta_{z, j}^{q} \Delta z_{t-j}+\sum_{j=1}^{M-1} \beta_{r, j}^{q} \Delta r_{t-j}+\sum_{j=0}^{M-1} \beta_{p, j}^{q} \Delta p_{t-j}+\epsilon_{t}^{q}
\end{aligned}
$$

identifies the investment-specific technology shock $\epsilon_{t}^{q}$. The long-run restriction is imposed by differencing all the regressors in $x_{t}$ apart from the relative investment goods price itself (note that $\Delta^{2}$ is the second difference operator). Moreover, we exclude the contemporaneous value of the Federal Funds rate from this regression. This implements the short-run assumption on the Fed's information set. Since $\epsilon_{t}^{q}$ may be correlated with $\Delta a_{t}$ (via equation 5) and $z_{t}$ (via equation 7), we estimate equation (4) with 2SLS. The instruments are a constant, the vector $\left[\Delta q_{t-j}, \Delta a_{t-j}, z_{t-j}, r_{t-j}, p_{t-j}\right]_{j=1}^{M}$ and $\hat{\epsilon}_{t}^{p}$ (the estimate of $\epsilon_{t}^{p}$ ). The third equation of the SVAR:

$$
\begin{aligned}
\Delta a_{t}=\alpha^{a} & +\sum_{j=0}^{M} \beta_{q, j}^{a} \Delta q_{t-j}+\sum_{j=1}^{M} \beta_{a, j}^{a} \Delta a_{t-j} \\
& +\sum_{j=0}^{M-1} \beta_{z, j}^{a} \Delta z_{t-j}+\sum_{j=1}^{M-1} \beta_{r, j}^{a} \Delta r_{t-j}+\sum_{j=0}^{M-1} \beta_{p, j}^{a} \Delta p_{t-j}+\epsilon_{t}^{a}
\end{aligned}
$$

identifies the neutral technology shock $\epsilon_{t}^{a}$. Note that we difference all regressors - except for $\Delta q_{t}$ and $\Delta a_{t}$ - and exclude the contemporaneous value of the Federal Funds rate. We estimate equation (5) using 2SLS, given that $\epsilon_{t}^{a}$ may depend on $z_{t}$ (via equation 7) and $q_{t}$ (via equation 4). The instruments employed above are extended to include the estimate of $\epsilon_{t}^{a}$; i.e., $\hat{\epsilon}_{t}^{a}$. The fourth equation of the SVAR:

$$
r_{t}=\alpha^{r}-\beta_{q, 0}^{r} \Delta q_{t}-\beta_{a, 0}^{r} \Delta a_{t}-\beta_{z, 0}^{r} z_{t}-\beta_{p, 0}^{r} p_{t}+\sum_{j=1}^{M} \beta_{x, j}^{r} x_{t-j}+\epsilon_{t}^{r}
$$

identifies the monetary policy shock $\epsilon_{t}^{r}$. This equation is estimated with ordinary least squares.

Following Altig et al. (2011), we estimate the remaining parameters for the vector $z_{t}$. The components of $z_{t}$ are denoted by $z_{t}^{i}, i=1, \ldots, 5$. The parameters of the first equation are obtained by estimating:

$$
\begin{aligned}
z_{t}^{1}=\alpha^{1} & +\sum_{j=0}^{M} \beta_{q, j}^{1} \Delta q_{t-j}+\sum_{j=0}^{M} \beta_{a, j}^{1} \Delta a_{t-j} \\
& +\sum_{j=1}^{M} \beta_{z, j}^{1} z_{t-j}+\sum_{j=1}^{M} \beta_{r, j}^{1} r_{t-j}+\sum_{j=0}^{M} \beta_{p, j}^{1} p_{t-j}+\epsilon_{t}^{1}
\end{aligned}
$$


employing the above-used instruments including the vector of estimated shocks $\left[\hat{\epsilon}_{t}^{p}, \hat{\epsilon}_{t}^{q}\right.$, $\left.\hat{\epsilon}_{t}^{a}\right]^{\prime}$. The second equation extends the set of regressors with $z_{t}^{1}$ and the list of instruments with $\hat{\epsilon}_{t}^{1}$. We continue this procedure recursively for all the variables included in $z_{t}$.

In order to determine the optimal VAR order $(M)$, we apply the standard sequential likelihood ratio test (see e.g. Lütkepohl 2005, Chapter 4.2.2), which rejects $M=4$ at the $1 \%$ significance level. The choice to use a lag length beyond one year is also supported by the existing literature on energy price shocks (Hamilton \& Herrera 2004). In addition, we test the null hypothesis of zero serial correlation using bootstrapped multivariate Portmanteau (Q) statistics (Altig et al. 2011). On the basis of this test, we do not reject the null hypothesis for $M=5$.

\section{Results}

\subsection{Dynamic Responses to Structural Shocks}

We modify the code by Altig et al. (2011) to estimate the coefficients and to compute the impulse responses to the four identified structural shocks. ${ }^{13}$ We examine the impulse response functions at horizons up to 32 quarters. The graphs depict the responses based on bootstrap sampling over 3,000 replications, where the first 1,000 draws are used to correct for small sample bias and departures from non-normality (Kilian 1998a,b). ${ }^{14}$ The solid line is the median estimate. The gray shaded areas represent the associated $60 \%, 70 \%, 80 \%$ and $90 \%$ non-centered confidence intervals. For the reader's convenience, Figures (3)-(5), (7) in the Appendix contrast the impulse responses of the "bandpass filter specification" (a panels) with the impulse responses of the "level specification" (b panels).

\subsubsection{Commodity Price Shocks}

Figure (3) depicts the impulse responses to the identified commodity price shock. We find that this shock triggers a temporary rise in the commodity price index, peaking shortly after the initial increase before slowly returning to its steady state level. Moreover, we observe a spike in the inflation rate, indicating that aggregate consumer prices are very flexible in response to commodity price shocks. In the following periods, the inflation rate declines sharply. The unexpected surge in the inflation rate prompts the Fed to elevate the nominal interest rate for a protracted period (about 6-8 quarters). ${ }^{15}$ Consequently, the inflation rate falls below normal about two years after the shock. We also note that the relative price of investment goods decreases slightly, but the effect disappears

\footnotetext{
${ }^{13}$ We thank Lawrence Christiano for making the code available on his website.

${ }^{14}$ The Jarque-Bera test statistics reject the null hypothesis that the commodity price shocks and the monetary policy shocks are normally distributed at the $1 \%$ significance level.

${ }^{15}$ The peak response of the Federal Funds rate corresponds to 30 basis points. We infer this value from the level specification (see Figure 3, panel b).
} 
relatively quickly. The adjustment paths of output, per-capita hours, employment, hours per worker, consumption, and investment display significant U-shaped responses. The estimated impulse responses of output and employment are qualitatively consistent with the results of Blanchard \& Galí (2010) — output and employment decline persistently after a lag of 3-5 quarters and reach a trough after about ten quarters.

In this context, Bernanke et al. (1997) argue that a substantial part of the recessionary effects of commodity price shocks is not due to the direct impact of higher producer prices, but rather due to the systematic contractionary response of the Federal Reserve. ${ }^{16}$ Their conclusion stems from a counterfactual exercise (suggested by Sims \& Zha 2006) which presumes that the Federal Funds rate is kept constant when the U.S. economy is hit by an unexpected increase in commodity prices. In the following, we perform the same counterfactual exercise using our estimated SVAR model. Importantly, our approach differs in many aspects from theirs as we adopt several suggestions - e.g. a linear SVAR model (Kilian \& Vigfusson 2011) with a lag length beyond one year (Hamilton \& Herrera 2004) - made in the subsequent debate. We observe that the imputed counterfactual movements in the Federal Funds rate deviate only moderately from the original series (see Figure 8). For this reason, we believe that our results are less prone to changing parameters due to the Lucas (1976) critique.

Figure (9) contrasts the impulse response functions of output, per-capita hours and the inflation rate in the bandpass filter specification (top panel) with the impulse responses under the counterfactual assumption (bottom panel). Indeed, we are unable to observe a significant downturn in output and per-capita hours if the Fed stayed passive. There is only an insignificant decline in output that occurs with a lag of about two years. The initial spike in the inflation rate, on the other hand, seems identical to the one estimated in the bandpass filter specification. At medium horizons (10-20 quarters), however, the counterfactual response cannot replicate the significant disinflationary rebound in CPI inflation. Thus, we conclude that the contractionary monetary policy feedback rule helped the Federal Reserve to achieve price stability in the long run, yet at the cost of a significant economic downturn in output and per-capita hours. ${ }^{17}$

In addition, Figure (10) illustrates the impulse responses of two CPI sub-indices; i.e. the so-called core inflation rate (all items less food and energy) and its counterpart (food and energy only). We observe that the spike in the headline inflation rate is mainly due to a sharp rise in food and energy prices. The core inflation rate, on the other hand, shows

\footnotetext{
${ }^{16}$ This view did not remain unchallenged. Herrera \& Pesavento (2009, p. 107), on the other hand, find that "the systematic monetary policy response dampened fluctuations in economic activity during the 1970s". Furthermore, Barsky \& Kilian (2002) argue that shifts in the monetary policy regime following the breakdown of the Bretton Woods system triggered the Great Stagflation of the 1970s.

${ }^{17}$ Kilian \& Lewis (2011), on the other hand, perform an alternative counterfactual exercise which assumes that the Fed does not respond directly to oil price shocks, but to the movements in other macroeconomic aggregates triggered by these shocks. They conclude that monetary policy responses did not cause large fluctuations in U.S. output.
} 
a lower — but still significant — and more persistent increase. This indicates that a little price rigidity at the level of intermediate goods may translate into persistent inflation movements in other sectors of the economy (Basu 1995) - so-called second-round effects. We also find a marginally significant disinflationary rebound in both CPI sub-indices at medium horizons. Moreover, by repeating the above-described counterfactual exercise, we notice that the initial increase in both sub-indices remained virtually unchanged if the Federal Reserve stayed passive. The disinflationary rebound, however, disappears in both impulse responses. Therefore, we conclude that the Fed's contractionary monetary policy feedback rule is unable to avoid second-round effects in the short run. Yet, it exhibits medium-run disinflationary effects which help the Federal Reserve to achieve price stability at longer forecast horizons.

\subsubsection{Monetary Policy Shocks}

Figure (4) shows the responses to an expansionary shock in monetary policy. This shock represents a drop in the Federal Funds rate, due to an unexpected deviation from the Fed's linear policy rule. Our identifying assumptions imply that the shock has only a temporary effect. Nevertheless, the Federal Funds rate remains below its steady state level for more than seven quarters. In response to this, we observe that output, percapita hours, employment, consumption, and investment rise gradually. Peak effects take place about 5-6 quarters after the monetary stimulus. At longer forecast horizons, the adjustment paths show a slight rebound. The response of the relative price of investment goods, on the other hand, is not significant. Overall, the shapes and elasticities of the responses are in line with the estimates by Ravn \& Simonelli (2008). Only labor input indicators behave slightly different. Employment seems somewhat less elastic. Hours per worker even display a very mild downturn. Consistent with Sims (1992), the impulse response of the inflation rate drops on impact, followed by a slow and persistent increase. According to our estimates, the inclusion of the commodity price index reduces the size of the drop slightly, but leaves the shape of the inflation response unchanged. This indicates that the "price puzzle" is a robust feature of the data (Hanson 2004).

Furthermore, we observe that an unexpected cut in the Federal Funds rate induces a slow, but persistent increase in commodity prices. The maximum impact does not occur until four to five years after the shock. In comparison to Anzuini et al. (2012), our estimated impulse response is much more gradual and resembles (qualitatively as well as quantitatively) the impulse response of the consumer prices index (i.e., the cumulative response of the inflation rate). In other words, the commodity price index shows no significant response in real terms. 


\subsubsection{Neutral Technology Shocks}

Figure (5) illustrates the impulse response functions to the identified neutral technology shock. We observe that a permanent improvement in labor productivity induces a longlasting rise in output and consumption. On impact, both variables jump up and then remain well above their original value for the entire time horizon. Moreover, the shock produces a large and protracted hump-shaped response in investment. The inflation rate falls on impact and then asymptotes to its steady-state level within four years. There is also a modest increase in the relative price of investment goods, but the effect disappears relatively quickly. The impulse response of per-capita hours is positive and marginally significant at the $10 \%$ level. A very similar response can be observed for the employment rate. Hours per worker, on the other hand, rise on impact and then slowly return to their steady state. Quantitatively, however, the impact of the intensive margin is small. The estimated impulse responses differ only in one important respect from those obtained by Altig et al. (2011). We find that the increase in consumption is not gradual, but rather abrupt.

The left panel of Figure (6) documents that the response of hours worked to neutral technology shocks is extremely sensitive to the treatment of the data ${ }^{18}$ when the information set is reduced to three variables $\left\{q_{t}, a_{t}, h_{t}\right\}$ following the set-up in Canova et al. (2010). If we remove the low-frequency movements - either by applying the one-sided bandpass filter, by taking first differences, by including a time trend and two structural breaks in level and trend, or by including the corresponding Francis \& Ramey (2009) hours time series in the level specification - the estimated hours response is significantly negative. This result is consistent with the findings of Galí (1999) and Canova et al. (2010). Instead, if per-capita hours enter the VAR in levels, the response is significantly positive (Christiano et al. 2003, 2004).

The right panel of Figure (6) shows the response of hours worked when the information set is large. We observe that the dynamic response is positive and marginally significant at the $10 \%$ level across all specifications. Only the dummy specification predicts a negative response during the first few quarters, but the confidence intervals are wide. Interestingly, we are also able to replicate the counterfactual exercise conducted by Fernald (2007). When all high and medium frequencies in per-capita hours are reversed, the small-scale SVAR model predicts a significantly positive response. This outcome is driven by the distortionary low-frequency movements. The counterfactual large-scale SVAR model, on the other hand, predicts that the hours response flips horizontally. This result is consistent with both the bandpass filter specification and the level specification. Thus, we conclude

\footnotetext{
${ }^{18}$ Difference specification: Like the level specification, but also per-capita hours enter in first differences. Dummy specification: We extend the level specification to include a time trend and two structural breaks in level and trend at the dates 1973Q2 and 1997Q2 (see Fernald 2007). The Francis \& Ramey (2009) hours time series is taken from Valerie A. Ramey's website, which is gratefully acknowledged.
} 
that the low-frequency bias (present in the level specification) and the misspecification error (induced by overdifferencing) become much less important when the information set is sufficiently large. ${ }^{19}$

\subsubsection{Investment-Specific Technology Shocks}

Figure (7) displays the effects of an investment-specific technology shock. This shock leads to an unexpected and permanent drop in the relative price of investment goods. We observe that all variables (except labor productivity) move together in response to this type of disturbance. Consistent with Altig et al. (2011), we find that the dynamic adjustment paths show a marked hump-shaped pattern, with peak effects occurring after 3-4 quarters. The impulse response of labor productivity remains insignificant for more than four years before eventually rising. This result illustrates that, on impact, the elasticity of per-capita hours is of the same magnitude as aggregate output (also here, most variation in labor input is due to adjustments along the extensive margin). Thus, investment-specific technology shocks seem far more important for the cyclical behavior of the labor market than neutral technology shocks.

\subsection{Importance of the Structural Shocks}

We now examine the relative importance of the four identified structural shocks for the variance of all variables included in our SVAR. First, we present the share of variation explained by each identified shock at different forecast horizons. However, as explained by Ravn \& Simonelli (2008), these figures do not allow us to draw direct conclusions about the importance of these shocks at business cycle frequencies. Therefore, we also compute the variance decomposition at business cycle frequencies (8-32 quarters) following the method proposed by Altig et al. (2011). In addition, we present the historical decomposition of the four identified structural shocks for aggregate output in the postwar period.

\subsubsection{Forecast Error Variance Decomposition}

Figure (11) displays the forecast error variance decomposition of three key macroeconomic variables (output, per-capita hours, and the inflation rate) at different horizons. We observe that neutral technology shocks explain a large share of the variation in output, particularly at long forecast horizons. Investment-specific technology shocks are the main determinant of fluctuations in per-capita hours, and the second most important determinant of fluctuations in output. Commodity price shocks (together with neutral

\footnotetext{
${ }^{19}$ This conclusion is in line with the results of Forni \& Gambetti (2011). They demonstrate that trivariate SVAR models do not capture sufficient information in order to find an unbiased estimate of the hours response to neutral technology shocks. Our choice to use a large information set is also supported by the outcome of cross-correlation tests (see Table 3).
} 
technology shocks) appear to be the primary driving force for movements in the inflation rate. Monetary policy shocks, on the other hand, explain only small shares of macroeconomic fluctuations. The joint explanatory power of all four shocks lies between $35 \%$ (inflation rate) and $48 \%$ (output) in the short run, and between $48 \%$ (inflation rate) and $68 \%$ (output) in the long run.

\subsubsection{Variance Decomposition at Business Cycle Frequencies}

We now investigate the variance decomposition at business cycle frequencies (see Table 4). The results show that commodity price shocks are a principal driving force for macroeconomic fluctuations. In particular, we find that commodity price shocks explain a large share of cyclical movements in inflation. ${ }^{20}$ The commodity price shock also turns out to be a very important determinant of cyclical fluctuations in many other macroeconomic variables (e.g., Federal Funds rate, investment, or consumption), second only to investment-specific technology shocks. Our result are in line with Edelstein \& Kilian (2009), who find that energy price shocks are a quantitative important (but not dominant) determinant of changes in aggregate consumption. ${ }^{21}$ Furthermore, the neutral technology shock explains only a considerable share of the variation in labor productivity - the endogenous variable in the equation that identifies the neutral technology shock. The monetary policy shock seems even less relevant. Even though the identifying assumptions of our VAR model are inherently not testable (Kilian \& Vega 2011), two observations provide indirect support for our strategy. On the one hand, only $11 \%$ of the changes in the nominal interest rate at business cycle frequencies are due to the unexpected shock. This implies that the Fed's monetary policy has followed a rule-based approach over our sample period (this conclusion is consistent with the results of Sims \& Zha 2006). On the other hand, more than $50 \%$ of the cyclical variability in the commodity price index is explained by the commodity price shock itself (note that, e.g., Cochrane 1994, finds even higher values). This result indicates that the contemporaneous exogeneity assumption is a reasonable identifying restriction.

The importance of investment-specific technology shocks is in line with the results of several recent SVAR studies by Fisher (2006), Ravn \& Simonelli (2008), Canova et al. (2010), and Altig et al. (2011). ${ }^{22}$ Altogether, the four identified shocks account for $49 \%$ $73 \%$ of business cycle volatility in the data. At first glance, however, it seems surprising

\footnotetext{
${ }^{20}$ This result is consistent with the finding of Hanson (2004), who shows that the commodity price index by the BLS (2012) is a good predictor of the inflation rate.

${ }^{21}$ Note that the same authors (Edelstein \& Kilian 2007) are unable to find a significant response in nonresidential fixed investment. Their data set, however, differs from ours in that we include consumer durables in investment.

${ }^{22}$ Smets \& Wouters (2007) and Mumtaz \& Zanetti (2012) draw the conclusion that neutral technology shocks are more important. Both sets of authors use a data set that includes consumer durables in consumption (and not in investment). Schmitt-Grohé \& Uribe (2011) argue that a common stochastic trend in neutral and investment-specific technology is the main driving force for the business cycle.
} 
that neutral technology shocks do not explain larger shares at business cycle frequencies. Therefore, we analyze also the explanatory power of neutral technology shocks across the whole spectrum (Figure 12). Indeed, we find that neutral technology shocks play a very important role in explaining macroeconomic fluctuations (particularly, output, labor productivity, and consumption), but at low frequencies.

\subsubsection{Historical Decomposition of Shocks}

As suggested by Edelstein \& Kilian (2009), the following section studies the cumulative effects of the identified structural shocks on output and inflation. The historical decomposition (see Figure 13) is based on the code provided by Altig et al. (2011). For stationarity considerations, we only report the results of the bandpass filter specification here (Kilian \& Lewis 2011). When all four identified structural shocks are considered, we observe that our SVAR model is able to replicate the cyclical behavior of output remarkably well. There are only two episodes in U.S. postwar history that exhibit a noticeable tracking error. The model explains neither the short recession in the late 1960s, nor the depth of the recession after the burst of the so-called dot-com bubble.

We also investigate the time series elicited by the four individual shocks. The graphs illustrate that their contribution varies considerably across different episodes in the U.S. postwar period. Commodity price shocks contribute most to the high degree of macroeconomic volatility - both in output and inflation - in the 1970s, particularly during and after the first OPEC oil crisis. ${ }^{23}$ In addition, commodity price shocks are also an important determinant of the double-dip in the early 1980s, the economic boom in the early 1990s, and the short early 2000s recession. We also note that commodity prices explain only a moderate share of inflation volatility in the later 1970s/early 1980s, but a large share of the decline in inflation during the last two recessions in our sample. Figure (8) evaluates the impact of the Fed's response to commodity price shocks. Therefore, we examine the cyclical movements of aggregate output in the absence of the contractionary monetary policy feedback rule. ${ }^{24}$ Interestingly, we observe that the monetary policy feedback rule - in particular, the contractionary response during the first OPEC oil crisis and the subsequent monetary easing — has amplified the output fluctuations caused by unexpected changes in commodity prices.

Consistent with the estimated impulse response functions, the counterfactual time series seems to lag the estimated path by about one year. Moreover, we note that the Fed's policy rule was note able to avoid the spike in the inflation rate around the year 1974, but had disinflationary effects in the subsequent period (a similar pattern can also be observed during the early 1900s recession). In other words, our SVAR indicates that

\footnotetext{
${ }^{23}$ This result is not as trivial as it seems. Kilian \& Lewis (2011), on the other hand, argue that the cumulative effects of oil price shocks were not large (even prior to 1987).

${ }^{24}$ See Section (3.1.1) for details and motivation of this counterfactual exercise.
} 
a contractionary monetary policy feedback rule may help the Federal Reserve to achieve price stability at longer forecast horizons, yet at the cost of output destabilization.

Monetary policy shocks, on the other hand, have played a role in the late 1960s recession, the double-dip in the early 1980s as well as in the subsequent recovery. Furthermore, in line with our previous results, we are unable to find a systematic relationship between neutral productivity shocks and fluctuations in aggregate output at business cycle frequencies. Neutral technology shocks seem rather important at low frequencies. For example, neutral productivity shocks suggest a deep recession between 1976 and 1983, reflecting the productivity slowdown in that period, and two long-lasting economic booms - the first in the mid 1980s and the second in the late 1990s. Consistent with Greenwood et al. (1997), we find that investment-specific technology growth was particularly strong during the productivity slowdown of other factors in the 1970s. Furthermore, investment-specific technology shocks appear to be a principal driving force for the 1960-61 recession and the following economic expansion, the 1973-75 recession (both output and inflation), the early 1980s recession as well as of the subsequent recovery.

\section{Robustness Analysis}

The following section presents a number of robustness checks. We investigate the sensitivity to the identifying assumptions (predeterminedness, global demand), the usage of the Thomson Reuters (2013) Continuous Commodity Index with time-invariant weights (see also Footnote 5), the data treatment, the choice of the lag length, and the selected sample period. We demonstrate that our results are robust across alternative model versions.

\subsection{Non-Predetermined Commodity Prices}

Section (2.2) assumes that no single shock (but the commodity price shock itself) has an impact on the contemporaneous value of the commodity price index. Rotemberg \& Woodford (1996) proposed this assumption to identify nominal oil price shocks. Given that the broad commodity price index may behave differently from the nominal oil price (Alquist et al. 2011), the current section examines the robustness of our identification strategy. Therefore, we relax the contemporaneous exogeneity assumption to allow for immediate responses in the commodity price index to unexpected changes in two main indicators of the U.S. economy (labor productivity growth and per-capita hours). This procedure is different to the one used by Blanchard \& Galí (2010), who have explored the consequences of an alternative recursive ordering of the variables. Importantly, as our SVAR is overidentified, we are able to eliminate these two identifying assumptions without imposing a new one. 
Consequently, the identified commodity price shock $\epsilon_{t}^{p}$ is now obtained by estimating:

$$
p_{t}=\alpha^{p}-\beta_{a, 0}^{p} \Delta a_{t}-\beta_{h, 0}^{p} h_{t}+\sum_{j=1}^{M} \beta_{x, j}^{p} x_{t-j}+\epsilon_{t}^{p}
$$

Since $\epsilon_{t}^{p}$ may be correlated with $\Delta a_{t}$ (via equation 5) and $h_{t}$ (via equation 7 ), we estimate equation (8) with 2SLS. The set of instruments includes a constant and the following vector: $:^{25}$

$$
\left[\Delta q_{t-j}, \Delta a_{t-j}, z_{t-j}, r_{t-j}, p_{t-j}\right]_{j=1}^{M+1} .
$$

We find that the estimated results are remarkably robust (see Figure 17). In particular, the CPI inflation rate behaves almost identical to Section (3.1.1). Also the median response of the Federal Funds rate matches the previous estimates closely - even though the confidence bands are somewhat wider. Moreover, Table (5) shows that the business cycle variance decomposition statistics remain virtually unchanged.

\subsection{External Demand}

The present identification procedure of the commodity price shock is unable to distinguish between supply- and demand-driven innovations. However, the assumption that commodity price shocks are contemporaneously exogenous to U.S. macroeconomic aggregates seems more defensible in the case of supply shocks (e.g., political strife in the Middle East, see Kilian 2008) than in the case of demand shocks. ${ }^{26}$ Therefore, we extend our SVAR by adding a variable that captures variations in global demand for commodity goods. In particular, we choose to include the natural log of the ratio of real exports to real imports of goods and services (see Table 2). Based on this series, we identify an external demand shock using short-run restrictions. Following Abbritti \& Weber (2010) or Kilian \& Lewis (2011), we assume that the process for the real export/import ratio is independent of the current realizations of all other variables but the commodity price index. $^{27}$

The impulse responses generated by the four remaining shocks, particularly by the commodity price shock (Figure 16a), remain virtually unchanged when we control for unexpected movements in external demand. In addition, the variance decomposition statistics at business cycle frequencies are remarkably robust (Table 5). We note only a mild reduction (4 percentage points) in the explanatory power of the commodity price

\footnotetext{
${ }^{25}$ Note that the parameters are overidentified, given that the number of instruments exceeds the number of parameters. Using an overidentifying restrictions test (Sargan 1964) we are unable to reject this specification at the $10 \%$ significance level.

${ }^{26}$ Kilian \& Murphy (2010) emphasize that political strife in the Middle East may not only disrupt oil supply, but also boost speculative demand.

${ }^{27}$ Note that the idea to disentangle commodity demand and supply shocks is due to Kilian (2009).
} 
shock with respect to the cyclical movements in the inflation rate. ${ }^{28}$ Figure (16b) illustrates the effects of the identified external demand shock. This shock represents a temporary but persistent rise in the real exports/imports ratio. We observe that the external demand shock causes a hump-shaped increase in the commodity price index, representing commodity price changes due to heightened global demand. Except for investment and consumption, all other variables show barely significant responses, which may be attributed to the fact that the U.S. is a relatively closed economy. Besides, the external demand shock is unable to explain significant shares in the business cycle variance of any variable but the real export/import ratio.

\subsection{Thomson Reuters Continuous Commodity Index}

Figure (18) shows the impulse responses when the Thomson Reuters (2013) Continuous Commodity Index with time-invariant weights (see Footnote 5) is used for the estimation of our SVAR model. In contrast to Section (3.1.1), the alternative commodity price index is more persistent with peak effects occurring about one year after the initial increase. Nevertheless, the relative impulse responses remain almost unchanged. Only the increase in the inflation rate seems to be more long-lived. After the initial increase, we observe that the inflation rate remains elevated for more than one year before eventually falling back to normal. We also note that the confidence bands are tighter. Consequently, the commodity price shock now becomes significantly more important in terms of the cyclical variance decomposition statistics (see Table 5), particularly with respect to inflation. The investment-specific technology shock, on the other hand, loses some of its explanatory power.

\subsection{Data Treatment}

Bandpass Filter vs. Level Specification The (b) panels of Figures (3)-(5), (7) and Table (4), respectively, display the impulse responses and the business cycle variance decomposition when we estimate the level specification of our SVAR model. We observe that all major conclusions survive this type of test. Even the response of per-capita hours to neutral technology shocks remains virtually unchanged (see also Section 3.1.3). The only notable difference between these two specifications is that the cyclical variance decomposition statistics of the commodity price shock are higher in the level specification, but the cyclical variance decomposition statistics of the investment-specific technology shock are higher in the bandpass filter specification. Altogether, these results indicate that the low-frequency bias becomes less important when the information set is sufficiently

\footnotetext{
${ }^{28}$ Alternatively, we have used the "rest of the world" GDP index (1972Q1-2006Q4) by Enders et al. (2011), the "global economic activity" index (1968Q1-2007Q4) by Kilian (2009) and the "world industrial production" index (1948Q1-2007Q4) by Baumeister \& Peersman (2012). Our (subsample) tests indicate that all indices yield similar results.
} 
large. Furthermore, the remarkable resemblance of the impulse responses suggests that concerns about leaving (Fernald 2007, Francis \& Ramey 2009, Canova et al. 2010) or removing (Gospodinov et al. 2011) low-frequency movements in the data are quantitatively not very important as long as the size of the information set is sufficiency large.

Treatment of the Hours Series In addition, Table (5) provides the cyclical variance decomposition statistics of output, per-capita hours, and the inflation rate under different model specifications. The figures confirm that our findings are robust to different filtering methods (differences, dummies, including the corresponding Francis \& Ramey (2009) hours time series in the level specification).

Treatment of the Commodity Price Index Figure (14) shows the impulse responses when the commodity price index is differenced prior to applying the one-sided bandpass filter. This implies that we now identify a permanent shock to the level of the commodity price index. We observe that the shapes of the impulse responses are almost identical to Section (10). The most interesting difference is that the response of labor productivity is no longer significant, indicating that the elasticities of output and per-capita hours are of the same magnitude. Also the business cycle variance decomposition statistics (see Table 5) are very similar.

\subsection{Lag Length}

The present section investigates whether the chosen lag length has any impact on our results. For this purpose, we reduce the number of lags to $M=4$. Table (5) shows that, in this case, the investment-specific technology shock becomes less important, but remains the principal driving force for output and per-capita hours over the business cycle. This indicates that our SVAR may suffer from "truncation bias" (Erceg et al. 2005) when the VAR order is insufficiently short. Qualitatively, however, we are unable to note any significant differences in the results.

\subsection{Subsample Stability}

Furthermore, we examine the subsample stability of the bandpass filter specification. Figure (15) illustrates the impulse responses to the identified commodity price shock before and after the appointment of Paul Volcker as chairman of the Board of Governors in August 1979. For this exercise - due to the smaller number of observations - we reduce the VAR order to $M=3$. Note that, when plotting these graphs, we normalize the standard deviation of the commodity price shock in both sub-periods to the one measured in the full sample. We observe that output and the (core) inflation rate respond less elastic in the late sub-sample, but remain statistically significant at the $10 \%$ level. This result 
is consistent with previous estimates by Blanchard \& Galí (2010), ${ }^{29}$ who attribute the milder response in the late sub-sample to $(a)$ the smaller share of oil in production, $(b)$ the decline in real wage rigidity, and $(c)$ improvements in monetary policy. ${ }^{30}$

In contrast to their study, our SVAR explicitly controls for the decreasing share of oil in production (by using a broad commodity price index with time-varying weights) and identifies neutral and investment-specific technology shocks. Our result of smaller second-round effects is consistent with their view of a decrease in real wage rigidity. Moreover, we find evidence in favor of increased credibility of monetary policy. In the pre-Volcker period, we notice that the Federal Funds rate stays above its steady state level for about five quarters. Following the initial rise, the Federal Reserve reduces the nominal interest rate and keeps it below its long-run mean for the next ten quarters. This pattern is known as stop-and-go monetary policy. ${ }^{31}$ In line with the conventional wisdom, we find no evidence for stop-and-go monetary policy in the post-Volcker period. The contractionary response in the post-Volcker period seems to be driven by the statistically significant hump-shape in the core inflation rate. Furthermore, consistent with the muted impulse responses, Table (5) shows that the explanatory power of the commodity price shock is somewhat lower in the post-Volcker period. ${ }^{32}$

\section{Summary and Conclusion}

This paper evaluates the importance of commodity price shocks in the U.S. business cycle. Therefore, we extend the standard set of identified shocks to include unexpected changes in commodity prices. The resulting SVAR shows that commodity price shocks are a very important driving force for macroeconomic fluctuations, second only to investmentspecific technology shocks. In particular, commodity price shocks explain a large share of cyclical movements in inflation.

The impulse response analysis shows that commodity price shocks generate significant U-shaped responses in output, consumption, and per-capita hours. Most notably, the inflation rate displays a significant spike, followed by a rapid return to the initial level. The unexpected surge in the inflation rate prompts the Fed to elevate the nominal interest rate. Results of a counterfactual exercise (in the style of Bernanke et al. 1997) indicate

\footnotetext{
${ }^{29}$ Our sub-sample periods are not exactly identical to the ones chosen by Blanchard \& Galí (2010). Given our nine-dimensional SVAR, the number of degrees of freedom is not sufficient in order to estimate the model accordingly. We also note that Edelstein \& Kilian (2009) or Herrera \& Pesavento (2009) find milder responses in the post-Volcker period.

${ }^{30}$ We also confirm their conclusion that the size of the shock in the post-Volcker period is larger than in the pre-Volcker period. This implies that the "Great Moderation" is not due to smaller commodity price shocks.

${ }^{31}$ The results of Evans \& Fisher (2011) suggest that the stop-and-go pattern in the Federal Funds rate is triggered by oil price shocks, while the significant hike is due to changes in prices of other commodities.

${ }^{32}$ Also note that the investment-specific technology shock is somewhat less important when we exclude the late 1990s Internet boom from our sample.
} 
that the systematic contractionary response helped the Federal Reserve to achieve price stability in the long run, yet at the cost of a significant economic downturn in output and per-capita hours.

Our SVAR model also addresses the hours response to neutral technology shocks. In particular, we find that the response of per-capita hours is positive and marginally significant. This result is surprising, given that we control for low-frequency movements in the data (Canova et al. 2010). Further investigations show that this result is very robust to the treatment of the data as long as the size of the information set is sufficiently large. This result, which is in line with the evidence found by Forni \& Gambetti (2011), confirms our choice to estimate a large-scale SVAR.

The sub-sample properties of our model are consistent with Blanchard \& Galí (2010). We find that the effects of a commodity price shock on output and the inflation rate are milder in the post-Volcker period, but remain statistically significant at the $10 \%$ level. Several further robustness checks confirm the findings of our model. In particular, we examine robustness to the choice of the lag length, the identifying assumptions, the specific commodity price index used, and the inclusion of an external demand shock (Abbritti \& Weber 2010). 


\section{References}

Abbritti, M. \& Weber, S. (2010), Labor market institutions and the business cycle: Unemployment rigidities vs. real wage rigidities, Working Paper Series No. 1183, European Central Bank.

Alquist, R., Kilian, L. \& Vigfusson, R. J. (2011), Forecasting the price of oil, in G. Elliott \& A. Timmermann, eds, 'Handbook of Economic Forecasting', 2 edn, Vol. 24 of Handbooks in Economics, Elsevier. Forthcoming.

Altig, D., Christiano, L., Eichenbaum, M. \& Lindé, J. (2011), 'Firm-specific capital, nominal rigidities and the business cycle', Review of Economic Dynamics 14(2), 225-247.

Anzuini, A., Lombardi, M. J. \& Pagano, P. (2012), The impact of monetary policy shocks on commodity prices, Temi di discussione (Economic working papers) No. 851, Bank of Italy, Economic Research and International Relations Area.

Barsky, R. \& Kilian, L. (2002), Do we really know that oil caused the great stagflation? A monetary alternative, in B. S. Bernanke \& K. Rogoff, eds, 'NBER Macroeconomics Annual 2001', Vol. 16 of NBER Macroeconomics Annual, The MIT Press, Cambridge, MA, pp. 137183.

Basu, S. (1995), 'Intermediate goods and business cycles: Implications for productivity and welfare', American Economic Review 85(3), 512-531.

Baumeister, C. \& Peersman, G. (2012), 'The role of time-varying price elasticities in accounting for volatility changes in the crude oil market', Journal of Applied Econometrics . Forthcoming.

Bernanke, B. S., Gertler, M. \& Watson, M. (1997), 'Systematic monetary policy and the effects of oil price shocks', Brookings Papers on Economic Activity 1, 91-142.

Blanchard, O. J. \& Galí, J. (2010), The macroeconomic effects of oil price shocks: Why are the 2000s so different from the 1970s?, in J. Galí \& M. Gertler, eds, 'International Dimensions of Monetary Policy 2007', University of Chicago Press, Chicago, IL, pp. 373-421.

Blanchard, O. J. \& Quah, D. (1989), 'The dynamic effects of aggregate demand and supply disturbances', American Economic Review 79(4), 655-673.

BLS (2012), BLS Handbook of Methods, Bureau of Labor Statistics, U.S. Department of Labor. Chapter 14: Producer Prices.

Canova, F., Lopez-Salido, D. \& Michelacci, C. (2010), 'The effects of technology shocks on hours and output: A robustness analysis', Journal of Applied Econometrics 25(5), 755-773.

Christiano, L. J., Eichenbaum, M. \& Evans, C. (1996), 'The effects of monetary policy shocks: Evidence from the flow of funds', Review of Economics and Statistics 78(1), 16-34.

Christiano, L. J., Eichenbaum, M. \& Vigfusson, R. (2003), What happens after a technology shock?, NBER Working Paper Series No. 9819, National Bureau of Economic Research.

Christiano, L. J., Eichenbaum, M. \& Vigfusson, R. (2004), 'The response of hours to a technology shock: Evidence based on direct measures of technology', Journal of the European Economic Association 2(2-3), 381-395.

Christiano, L. J. \& Fitzgerald, T. J. (2003), 'The band pass filter', International Economic Review 44(2), 435-465. 
Cochrane, J. H. (1994), 'Shocks', Carnegie-Rochester Conference Series on Public Policy 41(1), 295-364.

Commodity Research Bureau (2013), 'CRB BLS Spot Index'.

URL: http : //www. crbtrader.com/crbindex/ (last access: March 22, 2013).

Cummins, J. \& Violante, G. (2002), 'Investment-specific technical change in the United States (1947-2000)', Review of Economic Dynamics 5(2), 243-248.

DiCecio, R. (2009), 'Sticky wages and sectoral labor comovement', Journal of Economic Dynamics and Control 33(3), 538-553.

Edelstein, P. \& Kilian, L. (2007), 'The response of business fixed investment to changes in energy prices: A test of some hypotheses about the transmission of energy price shocks', The B.E. Journal of Macroeconomics 7(1), 35.

Edelstein, P. \& Kilian, L. (2009), 'How sensitive are consumer expenditures to retail energy prices?', Journal of Monetary Economics 56(6), 766-779.

Enders, Z., Müller, G. J. \& Scholl, A. (2011), 'How do fiscal and technology shocks affect real exchange rates? New evidence for the United States', Journal of International Economics 83(1), 53-69.

Erceg, C., Guerrieri, L. \& Gust, C. (2005), 'Can long-run restrictions identify technology shocks?', Journal of the European Economic Association 3(6), 1237--1278.

Evans, C. L. \& Fisher, J. D. M. (2011), What are the implications of rising commodity prices for inflation and monetary policy?, Chicago Fed Letter No. 286, The Federal Reserve Bank of Chicago.

Fernald, J. G. (2007), 'Trend breaks, long-run restrictions, and contractionary technology improvements', Journal of Monetary Economics 54(8), 2467-2485.

Fisher, J. D. M. (2006), 'The dynamic effects of neutral and investment-specific technology shocks', Journal of Political Economy 114(3), 413-451.

Forni, M. \& Gambetti, L. (2011), Testing for sufficient information in structural VARs, CEPR Discussion Paper No. 8209, Centre for Economic Policy Research, London.

Francis, N. \& Ramey, V. A. (2009), 'Measures of per capita hours and their implications for the technology-hours debate', Journal of Money, Credit and Banking 41(6), 1071-1097.

Galí, J. (1999), 'Technology, employment, and the business cycle: Do technology shocks explain aggregate fluctuations?', American Economic Review 89(1), 249-271.

Gertler, M., Sala, L. \& Trigari, A. (2008), 'An estimated monetary DSGE model with unemployment and staggered nominal wage bargaining', Journal of Money, Credit and Banking 40(8), 1713-1764.

Gordon, R. J. (1990), The Measurement of Durable Goods Prices, NBER Monograph, University of Chicago Press, Chicago, IL.

Gospodinov, N., Maynard, A. \& Pesavento, E. (2011), 'Sensitivity of impulse responses to small low frequency co-movements: Reconciling the evidence on the effects of technology shocks', Journal of Business and Economic Statistics 29(4), 455-467. 
Granger, C. W. J. (1969), 'Investigating causal relations by econometric models and crossspectral methods', Econometrica 37(3), 424-438.

Greenwood, J., Hercowitz, Z. \& Krusell, P. (1997), 'Long-run implications of investment-specific technological change', American Economic Review 87(3), 342-362.

Hamilton, J. D. (1994), Time Series Analysis, Princeton University Press, Princeton, New Jersey.

Hamilton, J. D. (2008), Oil and the macroeconomy, in S. N. Durlauf \& L. E. Blume, eds, 'The New Palgrave Dictionary of Economics', 2 edn, The New Palgrave Dictionary of Economics Online, Palgrave MacMillan. doi:10.1057/9780230226203.1215.

Hamilton, J. D. \& Herrera, A. M. (2004), 'Oil shocks and aggregate economic behavior: The role of monetary policy: Comment', Journal of Money, Credit and Banking 36(2), 265-286.

Hanson, M. S. (2004), 'The "Price Puzzle" reconsidered', Journal of Monetary Economics 51(7), 1385-1413.

Herrera, A. M. \& Pesavento, E. (2009), 'Oil price shocks, systematic monetary policy, and the "Great Moderation"', Macroeconomic Dynamics 13(01), 107-137.

Justiniano, A., Primiceri, G. E. \& Tambalotti, A. (2010), 'Investment shocks and business cycles', Journal of Monetary Economics 57(2), 132-145.

Kilian, L. (1998a), 'Confidence intervals for impulse responses under departures from normality', Econometric Reviews 17(1), 1-29.

Kilian, L. (1998b), 'Small-sample confidence intervals for impulse response functions', Review of Economics and Statistics 80(2), 218-230.

Kilian, L. (2008), 'The economic effects of energy price shocks', Journal of Economic Literature 46(4), 871-909.

Kilian, L. (2009), 'Not all oil price shocks are alike: Disentangling demand and supply shocks in the crude oil market,', American Economic Review 99(3), 1053-1069.

Kilian, L. \& Lewis, L. (2011), 'Does the Fed respond to oil price shocks?', Economic Journal 121(555), 1047-1072.

Kilian, L. \& Murphy, D. (2010), The role of inventories and speculative trading in the global market for crude oil, CEPR Discussion Papers No. 7753, Centre for Economic Policy Research.

Kilian, L. \& Vega, C. (2011), 'Do energy prices respond to U.S. macroeconomic news? A test of the hypothesis of predetermined energy prices', Review of Economics and Statistics 93(2), 660-671.

Kilian, L. \& Vigfusson, R. J. (2011), 'Are the responses of the U.S. economy asymmetric in energy price increases and decreases?', Quantitative Economics 2(3), 419-453.

Lütkepohl, H. (2005), New Introduction to Multiple Time Series Analysis, Springer, Berlin.

Lucas, R. J. (1976), 'Econometric policy evaluation: A critique', Carnegie-Rochester Conference Series on Public Policy 1(1), 19-46.

Lucas, Robert E, J. (1980), 'Two illustrations of the Quantity Theory of Money', American Economic Review 70(5), 1005-1014. 
Medina, J. P. \& Soto, C. (2005), Oil shocks and monetary policy in an estimated DSGE model for a small open economy, Working Papers No. 353, Central Bank of Chile.

Mumtaz, H. \& Zanetti, F. (2012), 'Neutral technology shocks and the dynamics of labor input: Results from an agnostic identification', International Economic Review 53(1), 235-254.

Ravn, M. O. \& Simonelli, S. (2008), 'Labor market dynamics and the business cycle: Structural evidence for the United States', Scandinavian Journal of Economics 109(4), 743-777.

Rotemberg, J. J. \& Woodford, M. (1996), 'Imperfect competition and the effects of energy price increases on economic activity', Journal of Money, Credit and Banking 28(4), 459-577.

Sargan, J. D. (1964), Wages and prices in the United Kingdom: A study in econometric methodology, in P. E. Hart, G. Mills \& J. K. Whitaker, eds, 'Econometric Analysis for National Economic Planning', Vol. 16 of Colston Papers, Butterworth, London, pp. 25-63.

Schmitt-Grohé, S. \& Uribe, M. (2011), 'Business cycles with a common trend in neutral and investment-specific productivity', Review of Economic Dynamics 14(1), 122-135.

Shapiro, M. D. \& Watson, M. W. (1988), Sources of business cycles fluctuations, in S. Fisher, ed., 'NBER Macroeconomics Annual 1988', Vol. 3 of NBER Macroeconomics Annual, The MIT Press, Cambridge, MA, pp. 111-156.

Sims, C. A. (1992), 'Interpreting the macroeconomic time series facts: The effects of monetary policy', European Economic Review 36(5), 975-1000.

Sims, C. A. \& Zha, T. (2006), 'Does monetary policy generate recessions?', Macroeconomic Dynamics 10(02), 231-272.

Smets, F. \& Wouters, R. (2007), 'Shocks and frictions in US business cycles: A Bayesian DSGE approach', American Economic Review 97(3), 586-606.

Thomson Reuters (2013), 'Thomson Reuters Equal Weight Continuous Commodity Index $(\mathrm{CCI})^{\prime}$.

URL: http : //thomsonreuters.com/content/financial/pdf/i_and_a/indices/cci_ factsheet.pdf (last access: March 22, 2013).

Thomson Reuters/Jefferies (2013), 'Thomson Reuters/Jefferies CRB Index'.

URL: http : //www.jefferies.com/Commodities/2cc/389 (last access: March 22, 2013). 


\section{A Tables}

\section{A.1 Sources and Definitions of Data}

\begin{tabular}{|c|c|c|c|}
\hline Series & Definition & Source & Mnemonic \\
\hline POP & civilian non-institutional population $16+$ & FRED & CNP16OV \\
\hline FFR & effective (net) Federal Funds rate & FRED & FEDFUNDS \\
\hline CPI & consumer price index (all urban consumers) & FRED & CPIAUCSL \\
\hline PPI & producer price index (crude materials) & FRED & PPICRM \\
\hline GOV & $\begin{array}{l}\text { real government consumption expenditures } \\
\& \text { gross investment }\end{array}$ & FRED & GCEC96 \\
\hline EXP & real exports of goods \& services & FRED & EXPGSC1 \\
\hline IMP & real imports of goods \& services & FRED & IMPGSC1 \\
\hline $\mathrm{HOU}$ & hours in the business sector & BLS & PRS84006033 \\
\hline OUT & real output per hour in the business sector & BLS & PRS84006093 \\
\hline EMP & employment in the business sector & BLS & PRS84006013 \\
\hline RPI & quality-adjusted relative price of investment & DiCecio (2009) & p_i \\
\hline $\mathrm{CON}$ & $\begin{array}{l}\text { real personal consumption expenditures } \\
\text { (nondurables \& services) }\end{array}$ & DiCecio (2009) & cndq $+\operatorname{csq}$ \\
\hline INV & $\begin{array}{l}\text { real quality adjusted gross private fixed } \\
\text { investment }+ \text { PCE durables, divided by } 100\end{array}$ & DiCecio (2009) & $\mathrm{r}$ _inv \\
\hline CCI & continuous commodity index & Datastream & NYFECRB \\
\hline
\end{tabular}

Table 1: This table displays the definitions of the raw series used. The BLS (2012, p. 5) defines crude materials for further processing as "[...] unprocessed commodities not sold directly to consumers. Crude foodstuffs and feedstuffs include items such as grains and livestock. The crude energy goods category consists of crude petroleum, natural gas to pipelines, and coal. Examples of crude nonfood materials other than energy include raw cotton, construction sand and gravel, and iron and steel scrap". Current and historical weights can be downloaded at: ftp : //ftp.bls.gov/pub/special.requests/ppi/; e.g. sopnew08.txt summarizes the weights in December 2007. We also thank Riccardo DiCecio for kindly sharing his data. The quality-adjustment follows Gordon (1990), Cummins \& Violante (2002), and Fisher (2006). Consumer durables are included in investment, but the change in inventories is not. We aggregate all monthly series to quarterly data.

\section{A.2 Definition of Variables in the SVAR}

\begin{tabular}{lrl}
\hline \hline \multicolumn{1}{c}{ Variable } & Symbol & \multicolumn{1}{c}{ Definition } \\
\hline \hline growth in labor p'tivity & $\Delta a_{t}$ & first difference of log (OUT) \\
growth in RPI & $\Delta q_{t}$ & first difference of log (RPI) \\
per-capita hours & $h_{t}$ & $\log$ of (HOU $/ \mathrm{POP})$ \\
\hline inflation rate & $\pi_{t}$ & first difference of log (CPI) \\
nominal interest rate & $r_{t}$ & $\mathrm{FFR}$ \\
employment rate & $n_{t}$ & $\log$ of (EMP/POP) \\
commodity price index & $p_{t}$ & $\log$ of (PPI) \\
consumption share & $c_{t}$ & $\log$ of (CON $/(\mathrm{CON}+\mathrm{INV}+\mathrm{GOV}+\mathrm{EXP}-\mathrm{IMP}))$ \\
investment share & $i_{t}$ & $\log$ of (INV/(CON+INV+GOV+EXP-IMP)) \\
\hline export/import ratio & $d_{t}$ & $\log$ of (EXP/IMP) \\
continuous commodity index & $c c i_{t}$ & $\log$ of (CCI) \\
\hline \hline
\end{tabular}

Table 2: This table displays the variables that enter the SVAR. The trivariate model (Canova et al. 2010) uses only the first three variables. The last two variables are only used for robustness checks. 


\section{A.3 Cross Correlations with Technology Shocks}

\begin{tabular}{rlrrrrrr}
\hline \hline & & \multicolumn{1}{c}{1} & \multicolumn{1}{c}{2} & \multicolumn{1}{c}{3} & \multicolumn{1}{c}{4} & \multicolumn{1}{c}{5} \\
\hline \hline$c_{t}$ & lag & 0.091 & 0.080 & 0.090 & 0.082 & 0.094 & 0.059 \\
& lead & 0.091 & 0.108 & 0.108 & 0.069 & 0.028 & 0.033 \\
$n_{t}$ & lag & -0.092 & -0.033 & -0.018 & -0.019 & -0.012 & -0.001 \\
& lead & -0.092 & -0.105 & -0.119 & -0.085 & -0.064 & -0.077 \\
$r_{t}$ & lag & -0.104 & -0.052 & -0.016 & 0.021 & 0.020 & 0.068 \\
& lead & -0.104 & $-0.152^{*}$ & $-0.190^{* *}$ & $-0.210^{* *}$ & $-0.197^{* *}$ & $-0.145^{*}$ \\
$\pi_{t}$ & lag & $-0.280^{* *}$ & -0.040 & -0.047 & -0.122 & -0.074 & -0.010 \\
& lead & $-0.280^{* *}$ & $-0.171^{*}$ & -0.136 & -0.136 & -0.107 & -0.112 \\
$i_{t}$ & lag & 0.001 & -0.026 & -0.012 & -0.033 & -0.045 & -0.033 \\
& lead & 0.001 & 0.012 & 0.038 & 0.076 & 0.100 & 0.094 \\
$p_{t}$ & lag & $-0.188^{* *}$ & -0.065 & -0.050 & -0.062 & -0.025 & 0.003 \\
& lead & $-0.188^{* *}$ & $-0.154^{*}$ & -0.134 & -0.129 & -0.103 & -0.100 \\
\hline \hline
\end{tabular}

(a) neutral technology

\begin{tabular}{|c|c|c|c|c|c|c|c|}
\hline & & 0 & 1 & 2 & 3 & 4 & 5 \\
\hline \multirow[t]{2}{*}{$\overline{c_{t}}$} & lag & -0.038 & $-0.143^{*}$ & -0.118 & $-0.148^{*}$ & -0.083 & 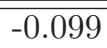 \\
\hline & lead & -0.038 & -0.017 & 0.018 & 0.033 & 0.044 & 0.064 \\
\hline \multirow[t]{2}{*}{$n_{t}$} & lag & -0.019 & 0.011 & 0.022 & 0.007 & 0.004 & 0.003 \\
\hline & lead & -0.019 & -0.036 & -0.081 & -0.111 & -0.115 & -0.091 \\
\hline \multirow[t]{2}{*}{$r_{t}$} & lag & 0.053 & 0.096 & 0.095 & 0.021 & 0.010 & -0.018 \\
\hline & lead & 0.053 & 0.003 & -0.056 & -0.075 & -0.048 & -0.074 \\
\hline \multirow[t]{2}{*}{$\pi_{t}$} & lag & -0.092 & $0.188^{* *}$ & $0.175^{*}$ & 0.016 & $0.156^{*}$ & 0.123 \\
\hline & lead & -0.092 & -0.012 & -0.015 & -0.137 & -0.100 & 0.014 \\
\hline \multirow[t]{2}{*}{$i_{t}$} & lag & -0.081 & 0.024 & 0.031 & 0.028 & 0.000 & 0.016 \\
\hline & lead & -0.081 & -0.104 & $-0.171^{*}$ & $-0.177^{*}$ & -0.133 & -0.103 \\
\hline \multirow[t]{2}{*}{$p_{t}$} & lag & -0.007 & 0.066 & 0.103 & 0.086 & 0.081 & 0.064 \\
\hline & lead & -0.007 & 0.000 & -0.021 & -0.051 & -0.002 & 0.038 \\
\hline
\end{tabular}

(b) investment-specific technology

Table 3: The table displays cross correlation coefficients between the the neutral and the investment specific technology shock series estimated using a trivariate SVAR following Canova et al. (2010), respectively, and the remaining six variables in our SVAR at leads and lags ( \pm 5 quarters). Stars $(*, * *)$ indicate significance at the $5 \%$ and $1 \%$ level, respectively. 


\section{A.4 Variance Decomposition at Business Cycle Frequencies}

\begin{tabular}{l|rrrrr}
\hline \hline & $\begin{array}{c}\text { commodity } \\
\text { prices }\end{array}$ & $\begin{array}{c}\text { monetary } \\
\text { policy }\end{array}$ & $\begin{array}{c}\text { neutral } \\
\text { tech }\end{array}$ & $\begin{array}{c}\text { investment } \\
\text { specific }\end{array}$ & $\begin{array}{c}\text { all four } \\
\text { shocks }\end{array}$ \\
\hline \hline$y_{t}$ & $12(8)$ & $8(5)$ & $11(7)$ & $21(12)$ & $52(14)$ \\
$y_{t} / h_{t}$ & $8(6)$ & $6(4)$ & $17(9)$ & $13(9)$ & $44(14)$ \\
$q_{t}$ & $9(6)$ & $3(3)$ & $11(7)$ & $29(15)$ & $51(16)$ \\
$h_{t}$ & $11(8)$ & $6(5)$ & $6(6)$ & $29(14)$ & $52(14)$ \\
$n_{t}$ & $11(8)$ & $7(5)$ & $6(6)$ & $27(14)$ & $51(14)$ \\
$h_{t} / n_{t}$ & $13(8)$ & $5(4)$ & $9(6)$ & $29(13)$ & $55(14)$ \\
$\pi_{t}$ & $17(9)$ & $6(4)$ & $12(8)$ & $14(10)$ & $49(14)$ \\
$r_{t}$ & $14(8)$ & $11(6)$ & $7(6)$ & $26(14)$ & $58(14)$ \\
$i_{t}$ & $14(8)$ & $8(5)$ & $9(6)$ & $20(12)$ & $51(13)$ \\
$c_{t}$ & $14(8)$ & $8(5)$ & $13(8)$ & $20(11)$ & $55(14)$ \\
$p_{t}$ & $51(15)$ & $4(3)$ & $7(6)$ & $11(8)$ & $73(14)$ \\
\hline \hline
\end{tabular}

(a) Benchmark Specification

\begin{tabular}{|c|c|c|c|c|c|}
\hline & $\begin{array}{c}\text { commodity } \\
\text { prices }\end{array}$ & $\begin{array}{c}\text { monetary } \\
\text { policy }\end{array}$ & $\begin{array}{c}\text { neutral } \\
\text { tech }\end{array}$ & $\begin{array}{l}\text { investment } \\
\text { specific }\end{array}$ & $\begin{array}{l}\text { all four } \\
\text { shocks }\end{array}$ \\
\hline $\bar{~} y_{t}$ & $\begin{array}{ll}17 \quad(8)\end{array}$ & $\overline{77(4)}$ & $\begin{array}{lll}14 \quad(9)\end{array}$ & $17(10)$ & $\overline{55(11)}$ \\
\hline$y_{t} / h_{t}$ & 11 & $5(3)$ & $16(10)$ & $19(10)$ & $51(12)$ \\
\hline$q_{t}$ & $13 \quad(7)$ & $3(2)$ & $10 \quad(6)$ & $18(14)$ & $43(14)$ \\
\hline$h_{t}$ & $14 \quad(8)$ & $6(4)$ & $9 \quad(8)$ & $20(12)$ & $50(13)$ \\
\hline$n_{t}$ & $14 \quad(8)$ & $6(4)$ & $9 \quad(8)$ & $23(13)$ & $52(13)$ \\
\hline$h_{t} / n_{t}$ & $17 \quad(8)$ & $5(4)$ & $9 \quad(7)$ & $14 \quad(9)$ & $45(11)$ \\
\hline$\pi_{t}$ & $25(10)$ & $5(4)$ & $9 \quad(7)$ & $17(11)$ & 57 (11) \\
\hline$r_{t}$ & $17 \quad(9)$ & $13(5)$ & $8 \quad(7)$ & $20(12)$ & $58(13)$ \\
\hline$i_{t}$ & $17 \quad(8)$ & $8(5)$ & 11 & $16(10)$ & $53(11)$ \\
\hline$c_{t}$ & $20 \quad(9)$ & $8(5)$ & $14 \quad(8)$ & $15 \quad(9)$ & 57 (11) \\
\hline$p_{t}$ & $60(11)$ & $6(4)$ & $5 \quad(4)$ & $7 \quad(4)$ & 77 (10) \\
\hline
\end{tabular}

(b) Level Specification

Table 4: The table displays the decomposition of variance at business cycle frequencies based on estimated spectral densities (following Altig et al. 2011). Numbers are means of point estimates across bootstrap simulations, numbers in parentheses are the corresponding standard deviations. 


\section{A.5 Robustness}

\begin{tabular}{|c|c|c|c|c|c|}
\hline & $\begin{array}{c}\text { commodity } \\
\text { prices }\end{array}$ & $\begin{array}{l}\text { monetary } \\
\text { policy }\end{array}$ & $\begin{array}{c}\text { neutral } \\
\text { tech }\end{array}$ & $\begin{array}{l}\text { investment } \\
\text { specific }\end{array}$ & $\begin{array}{l}\text { all four } \\
\text { shocks }\end{array}$ \\
\hline & \multicolumn{5}{|c|}{ Benchmark Specification } \\
\hline$\overline{y_{t}}$ & $12 \quad(8)$ & $8(5)$ & $11(7)$ & $21(12)$ & $\overline{52(14)}$ \\
\hline$h_{t}$ & $11(8)$ & $6(5)$ & $6(6)$ & $29(14)$ & $52(14)$ \\
\hline \multirow[t]{2}{*}{$\pi_{t}$} & $17 \quad(9)$ & $6(4)$ & $12(8)$ & $14(10)$ & $49(14)$ \\
\hline & \multicolumn{5}{|c|}{ Level Specification } \\
\hline$\overline{y_{t}}$ & $17 \quad(8)$ & $7(4)$ & $14 \quad(9)$ & $17(10)$ & $55(11)$ \\
\hline$h_{t}$ & $14 \quad(8)$ & $6(4)$ & $9(8)$ & $20(12)$ & $50(13)$ \\
\hline \multirow[t]{2}{*}{$\pi_{t}$} & $25(10)$ & $5(4)$ & $9 \quad(7)$ & $17(11)$ & $57(11)$ \\
\hline & \multicolumn{5}{|c|}{ Difference Specification } \\
\hline$y_{t}$ & $15 \quad(7)$ & $9(5)$ & $15(9)$ & $15(10)$ & $53(12)$ \\
\hline$h_{t}$ & $12(7)$ & $7(5)$ & $11(9)$ & $21(12)$ & $51(13)$ \\
\hline \multirow[t]{2}{*}{$\pi_{t}$} & $24 \quad(9)$ & $6(4)$ & $9(6)$ & $15(10)$ & $54(12)$ \\
\hline & \multicolumn{5}{|c|}{ Dummy Specification } \\
\hline$y_{t}$ & $16(8)$ & $8(5)$ & $13(8)$ & $17(10)$ & $54(11)$ \\
\hline$h_{t}$ & $15 \quad(8)$ & $6(4)$ & $7(6)$ & $21(13)$ & $50(13)$ \\
\hline \multirow[t]{2}{*}{$\pi_{t}$} & $27(10)$ & $6(4)$ & $8(6)$ & $12 \quad(9)$ & $53(11)$ \\
\hline & \multicolumn{5}{|c|}{ Francis \& Ramey (2009) Hours } \\
\hline$y_{t}$ & $11 \quad(6)$ & $6(4)$ & $15(9)$ & $18(11)$ & $50(12)$ \\
\hline$h_{t}$ & $9 \quad(6)$ & $6(4)$ & $9(8)$ & $22(13)$ & $46(13)$ \\
\hline \multirow[t]{2}{*}{$\pi_{t}$} & $19 \quad(9)$ & $4(3)$ & $8(7)$ & $19(13)$ & $50(12)$ \\
\hline & \multicolumn{5}{|c|}{ Commodity Prices in First Differences } \\
\hline$\overline{y_{t}}$ & $\begin{array}{ll}10 \quad(6) \\
\end{array}$ & $8(5)$ & 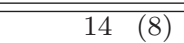 & $\overline{18(11)}$ & $\overline{50(14)}$ \\
\hline$h_{t}$ & $9(6)$ & $6(5)$ & $6(5)$ & $28(13)$ & $50(14)$ \\
\hline \multirow[t]{2}{*}{$\pi_{t}$} & $17 \quad(9)$ & $7(5)$ & $8(6)$ & $12 \quad(9)$ & $44(15)$ \\
\hline & \multicolumn{5}{|c|}{ Benchmark Specification with 4 Lags } \\
\hline$\overline{y_{t}}$ & $11 \quad(7)$ & 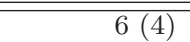 & $13 \quad(8)$ & $\begin{array}{cc}15 & (9)\end{array}$ & 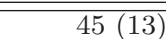 \\
\hline$h_{t}$ & $10 \quad(7)$ & $5(4)$ & $8(6)$ & $21(12)$ & $44(13)$ \\
\hline \multirow[t]{2}{*}{$\pi_{t}$} & $20(10)$ & $7(4)$ & $12(7)$ & $7(5)$ & $45(13)$ \\
\hline & \multicolumn{5}{|c|}{ Pre-Volcker Period (1959Q1-1979Q2) } \\
\hline$\overline{y_{t}}$ & $16(10)$ & $12(7)$ & $13(10)$ & $15(11)$ & $57(14)$ \\
\hline$h_{t}$ & $17(11)$ & $13(7)$ & $11(8)$ & $14(11)$ & $55(14)$ \\
\hline \multirow[t]{2}{*}{$\pi_{t}$} & $17(10)$ & $12(7)$ & $10 \quad(8)$ & $15 \quad(8)$ & $55(13)$ \\
\hline & \multicolumn{5}{|c|}{ Post-Volcker Period (1980Q1-2007Q4) } \\
\hline$\overline{y_{t}}$ & $\begin{array}{ll}9 \quad(7) \\
\end{array}$ & $8(5)$ & $\begin{array}{ll}8 & (7)\end{array}$ & $23(14)$ & 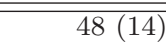 \\
\hline$h_{t}$ & $9 \quad(8)$ & $7(5)$ & $8(7)$ & $23(16)$ & $47(15)$ \\
\hline \multirow[t]{2}{*}{$\pi_{t}$} & $13 \quad(8)$ & $6(4)$ & $7 \quad(6)$ & $18(12)$ & $44(13)$ \\
\hline & \multicolumn{5}{|c|}{ External Demand Shock } \\
\hline$y_{t}$ & $10 \quad(7)$ & $7(5)$ & $11 \quad(7)$ & $20(12)$ & $\overline{54 \dagger(14)}$ \\
\hline$h_{t}$ & $10 \quad(7)$ & $6(5)$ & $7(6)$ & $28(15)$ & $57 \dagger(14)$ \\
\hline \multirow[t]{2}{*}{$\pi_{t}$} & $13 \quad(8)$ & $5(4)$ & $11(9)$ & $16(10)$ & $51 \dagger(14)$ \\
\hline & \multicolumn{5}{|c|}{ Non-Predetermined Commodity Prices } \\
\hline$y_{t}$ & $\overline{12}(9)$ & $7(5)$ & $12(8)$ & $18(11)$ & 49 (15) \\
\hline$h_{t}$ & $12 \quad(9)$ & $6(5)$ & $7(6)$ & $27(14)$ & $52(15)$ \\
\hline \multirow[t]{2}{*}{$\pi_{t}$} & $17(10)$ & $5(4)$ & $11(8)$ & $15(10)$ & $48(15)$ \\
\hline & & Thomson Reu & Zontinuous Cor & dity Index & \\
\hline$\overline{y_{t}}$ & $22(10)$ & $5(3)$ & $\begin{array}{ll}9 & (6)\end{array}$ & $\begin{array}{ll}14 & (9)\end{array}$ & $50(13)$ \\
\hline$h_{t}$ & $20(10)$ & $4(3)$ & $7(6)$ & $14(10)$ & $45(13)$ \\
\hline$\pi_{t}$ & $31(12)$ & $3(3)$ & $8 \quad(6)$ & $11 \quad(7)$ & $53(12)$ \\
\hline
\end{tabular}

Table 5: The table displays the decomposition of variance at business cycle frequencies based on estimated spectral densities (following Altig et al. 2011). Numbers are means of point estimates across bootstrap simulations, numbers in parentheses are the corresponding standard deviations. The "external demand shock" specification includes five shocks in total (denoted by a dag symbol †). 


\section{B Figures}

\section{B.1 Commodity Price Indices}

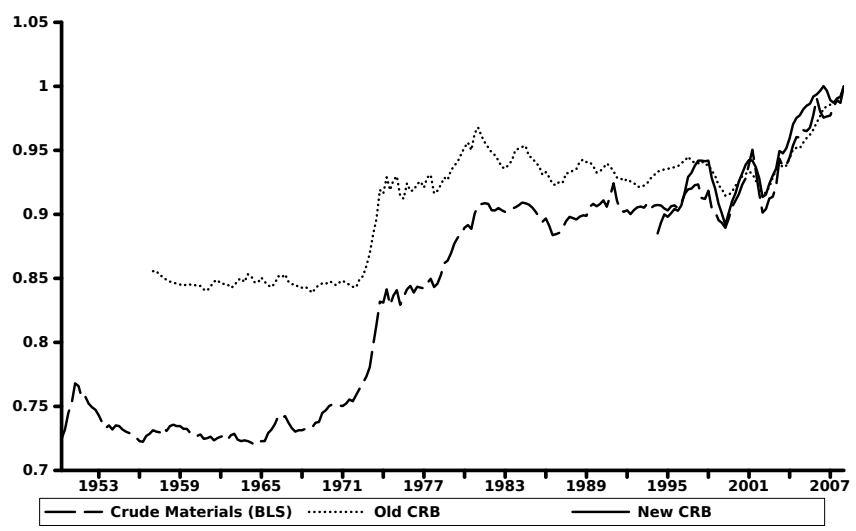

Figure 1: The figure illustrates the evolution of the "PPI: crude materials for further processing" index by the BLS (2012, p. 8, dashed line), the "old CRB" by Thomson Reuters (2013, calculated backwards until 1956Q4, dotted line), and the "new" Thomson Reuters/Jefferies (2013, solid line) CRB index, introduced in 2005, but calculated backwards until 1994Q1. All three indices are logged and normalized to unity in $2007 \mathrm{Q} 4$.

\section{B.2 Coherence Analysis}

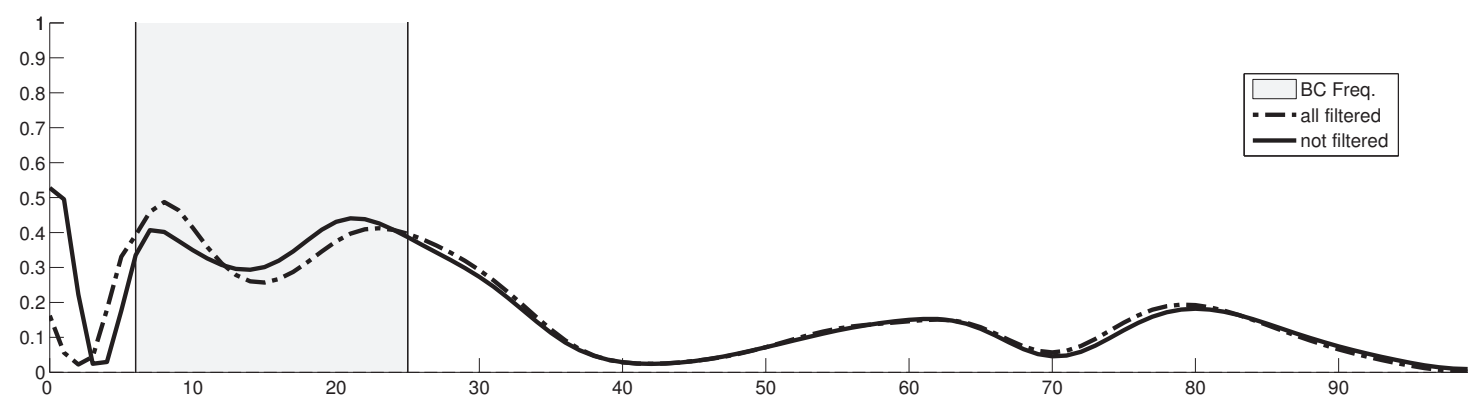

(a) all series are filtered

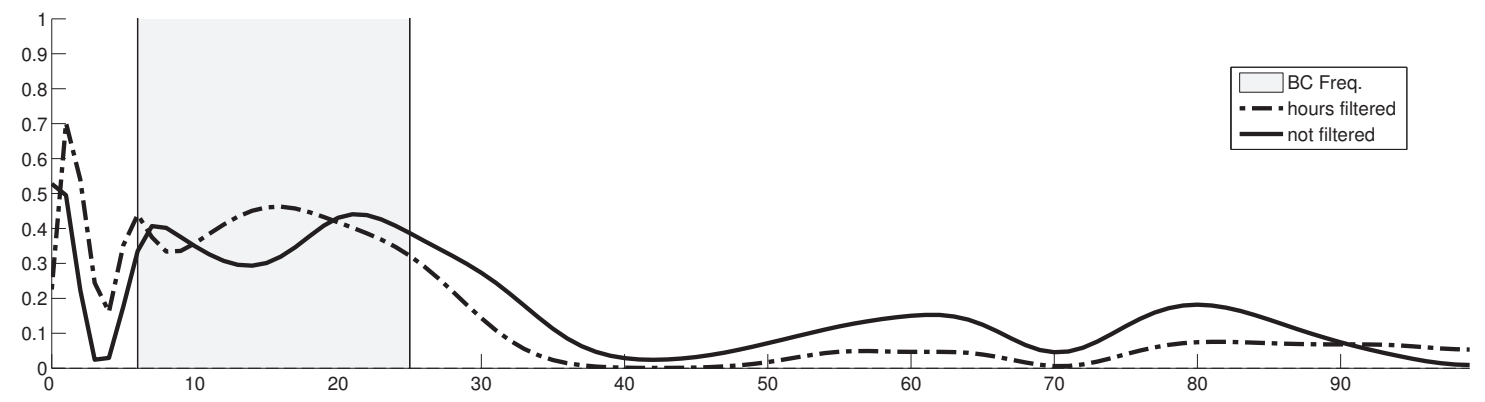

(b) only per-capita hours are filtered

Figure 2: The figure illustrates the coherence between labor productivity growth and per-capita hours, estimated with five lags. 


\section{B.3 Impulse Response Functions}
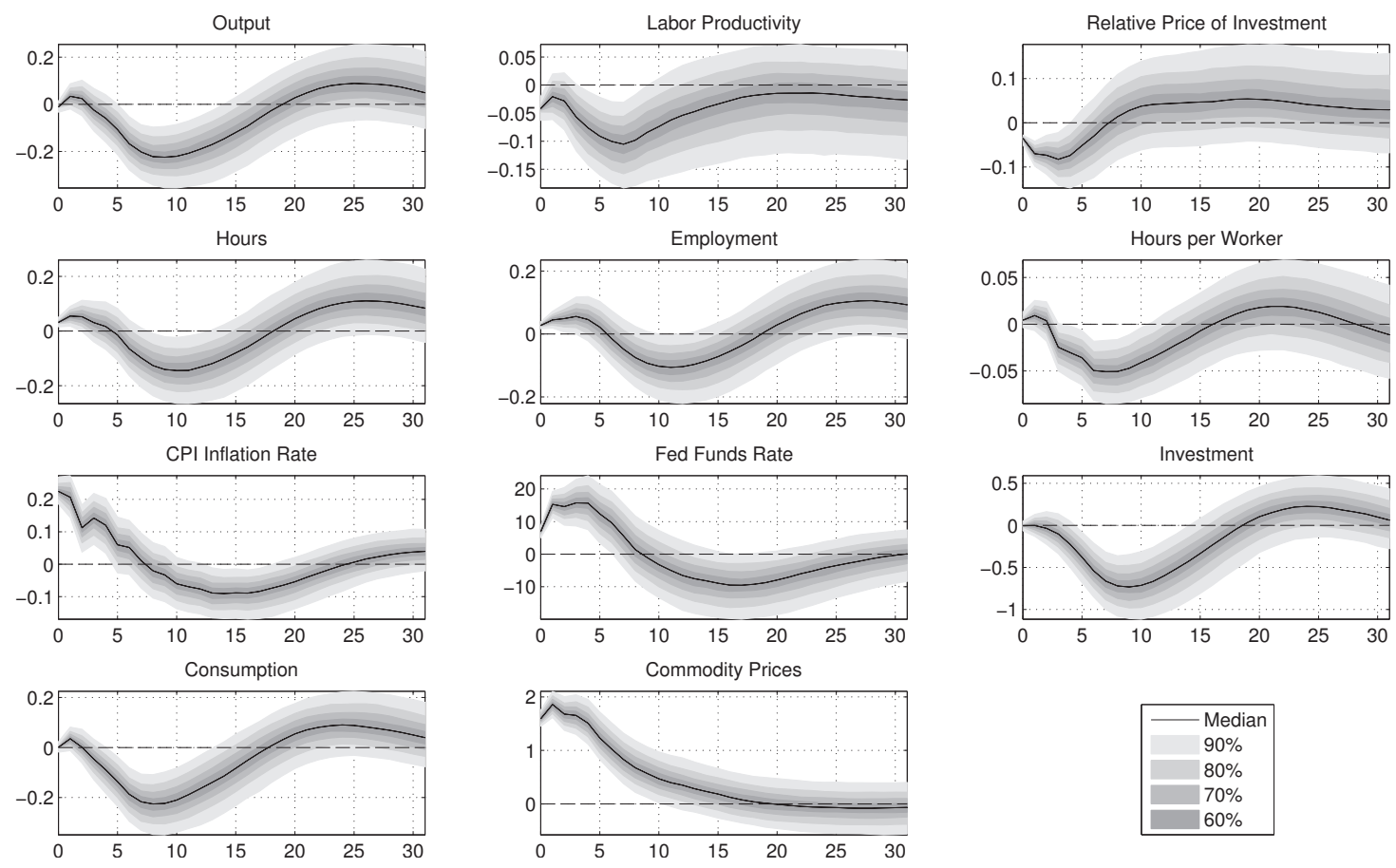

(a) Benchmark Specification
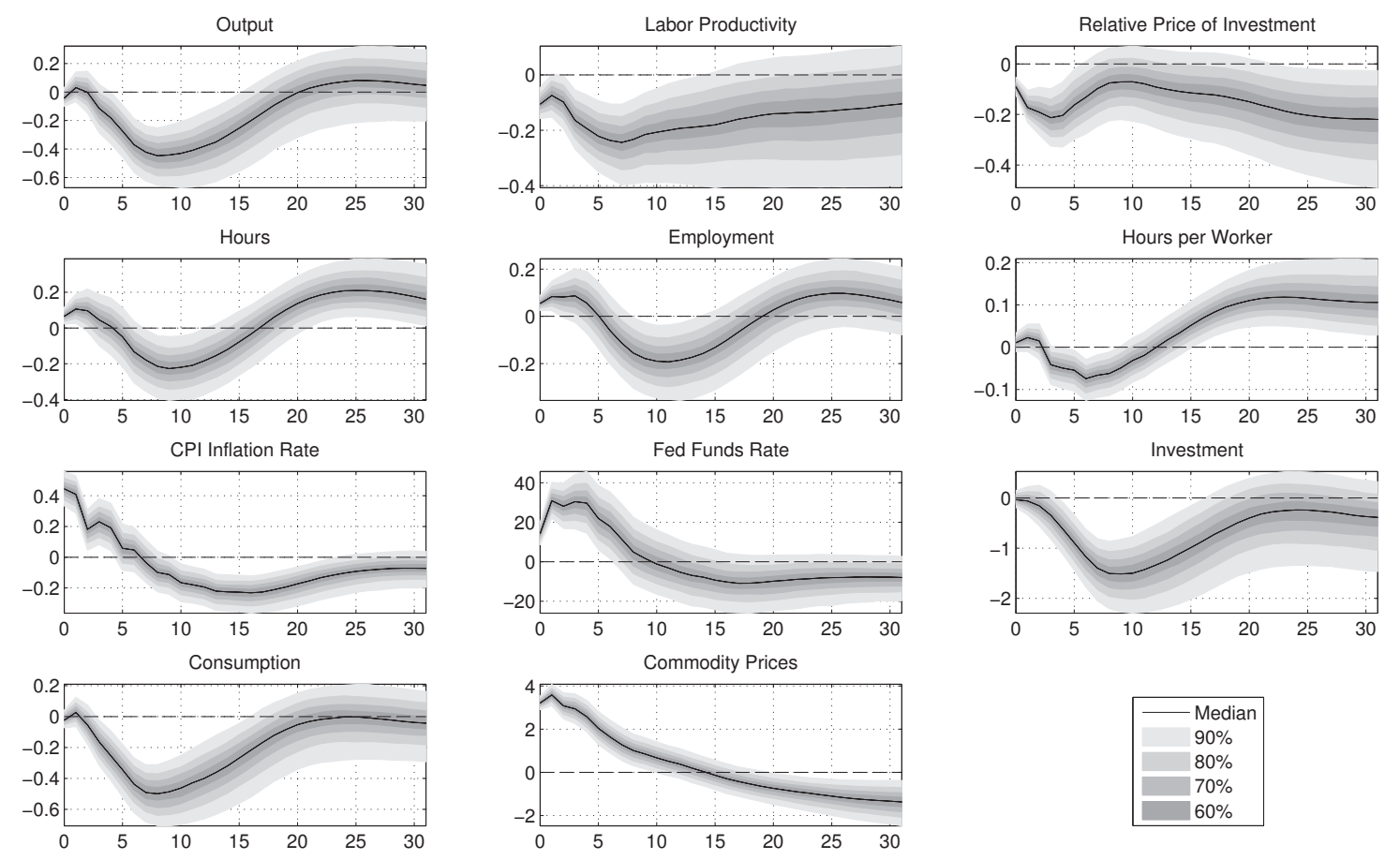

(b) Level Specification

Figure 3: The figure illustrates the impulse responses to a commodity price shock. 


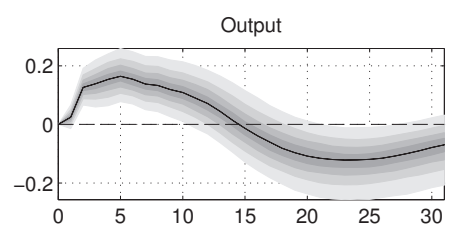

Hours
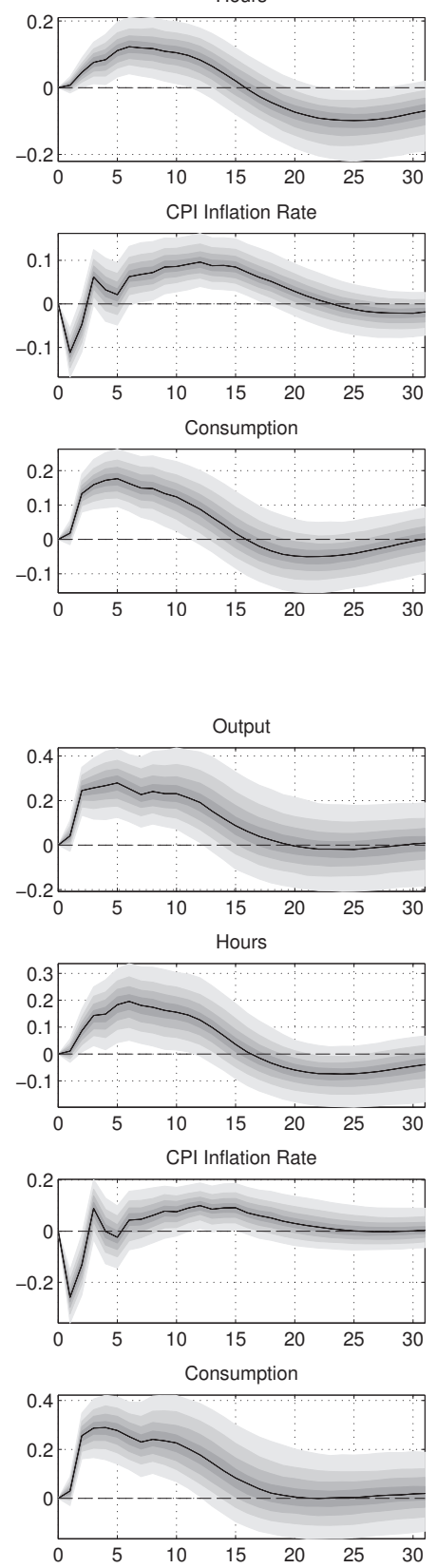
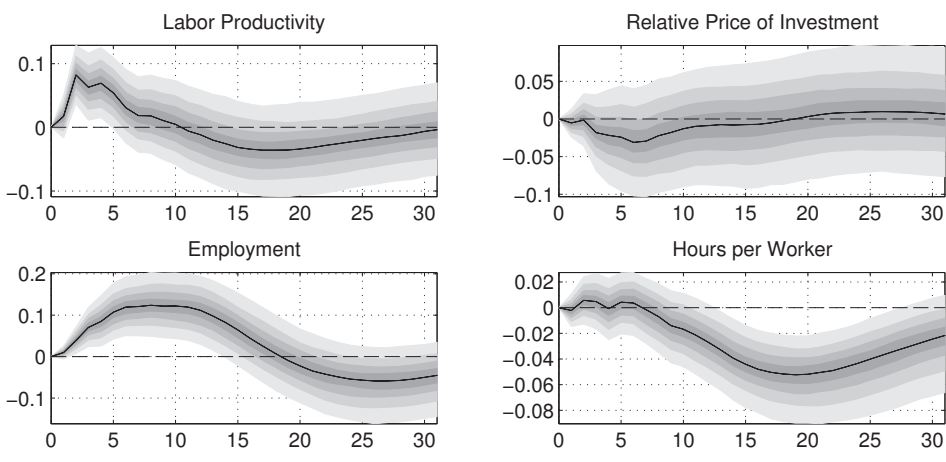

Fed Funds Rate
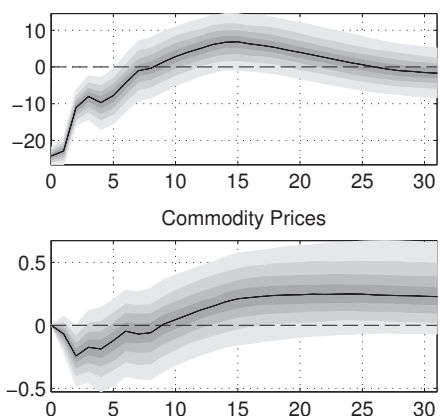

(a) Benchmark Specification
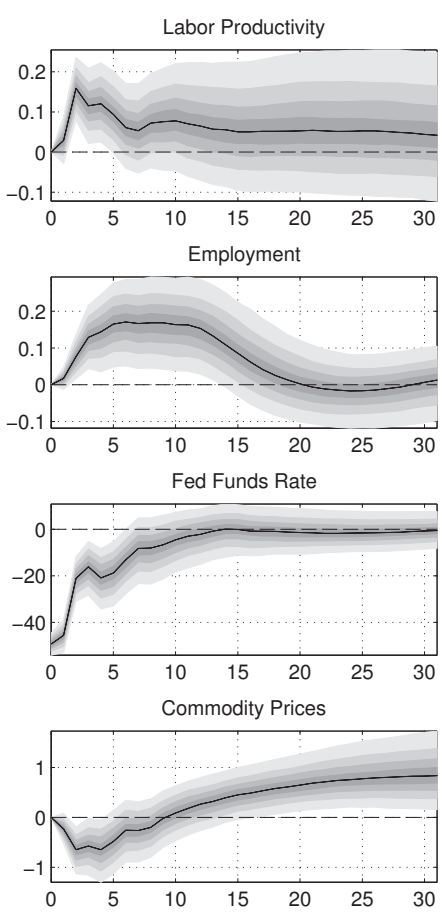

(b) Level Specification
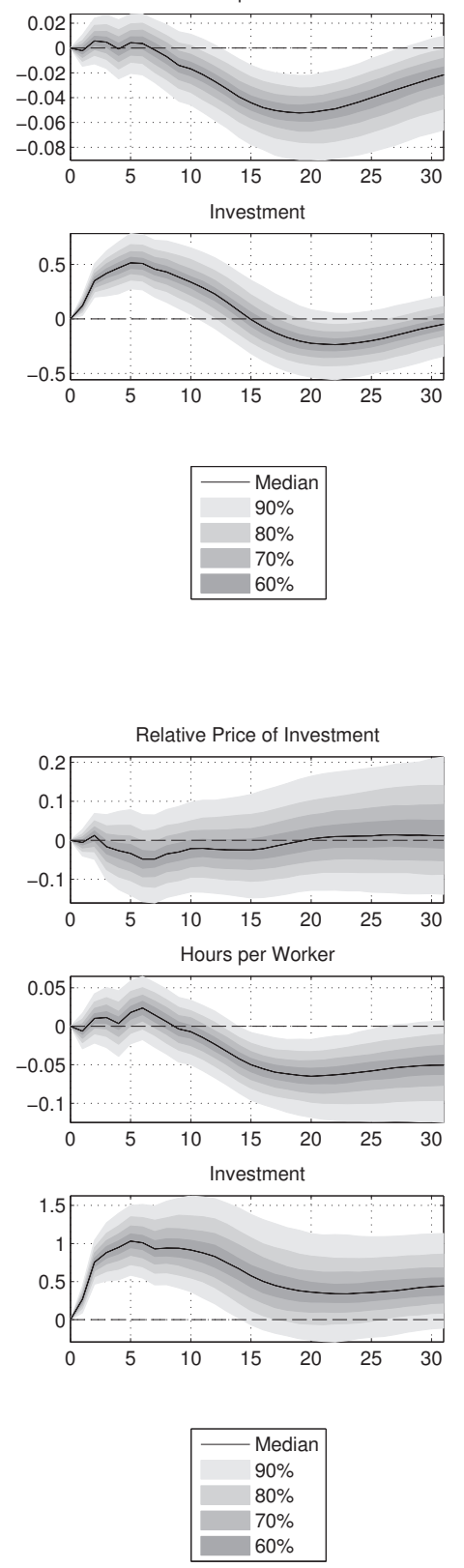

Figure 4: The figure illustrates the impulse responses to a monetary policy shock. 

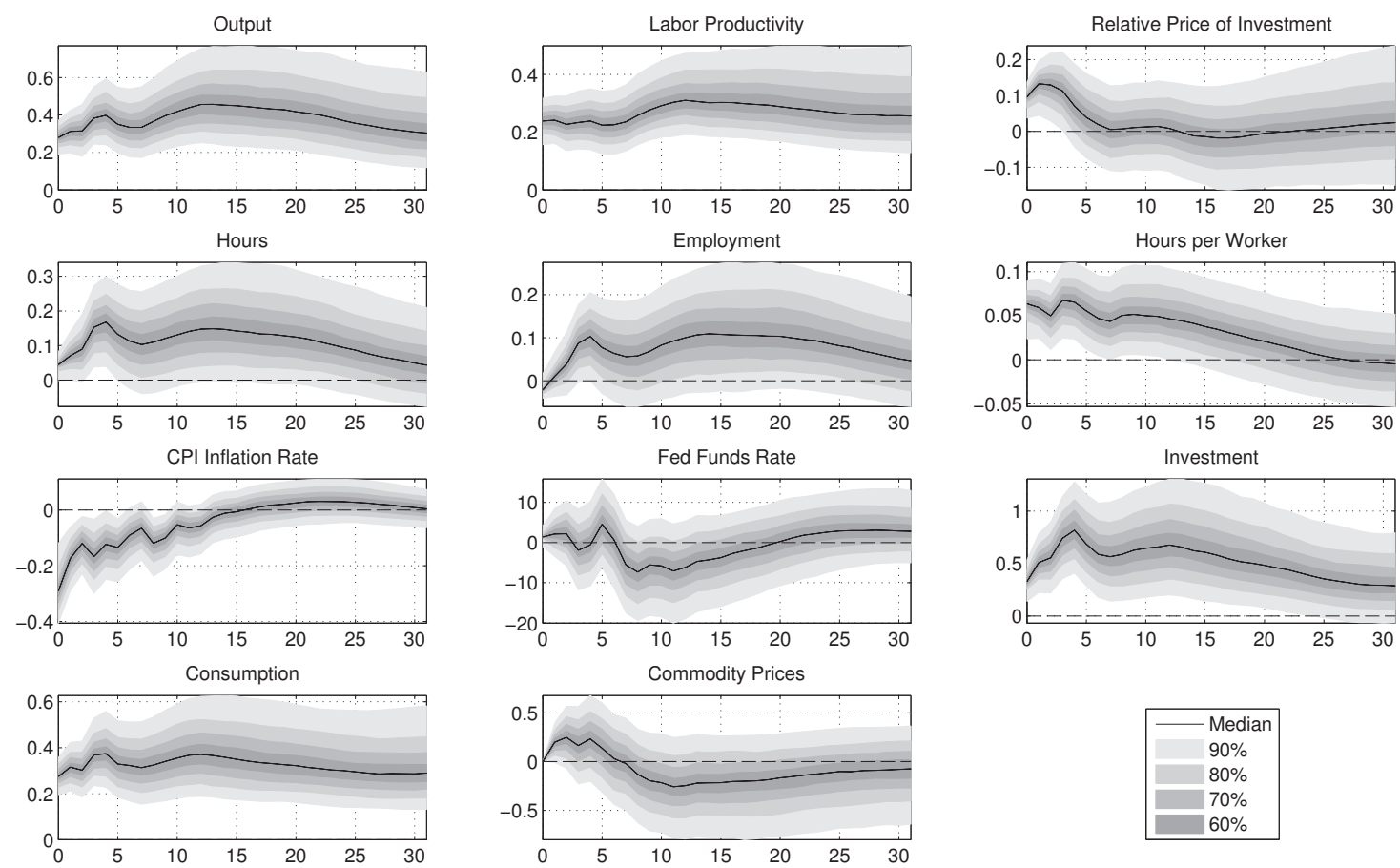

(a) Benchmark Specification
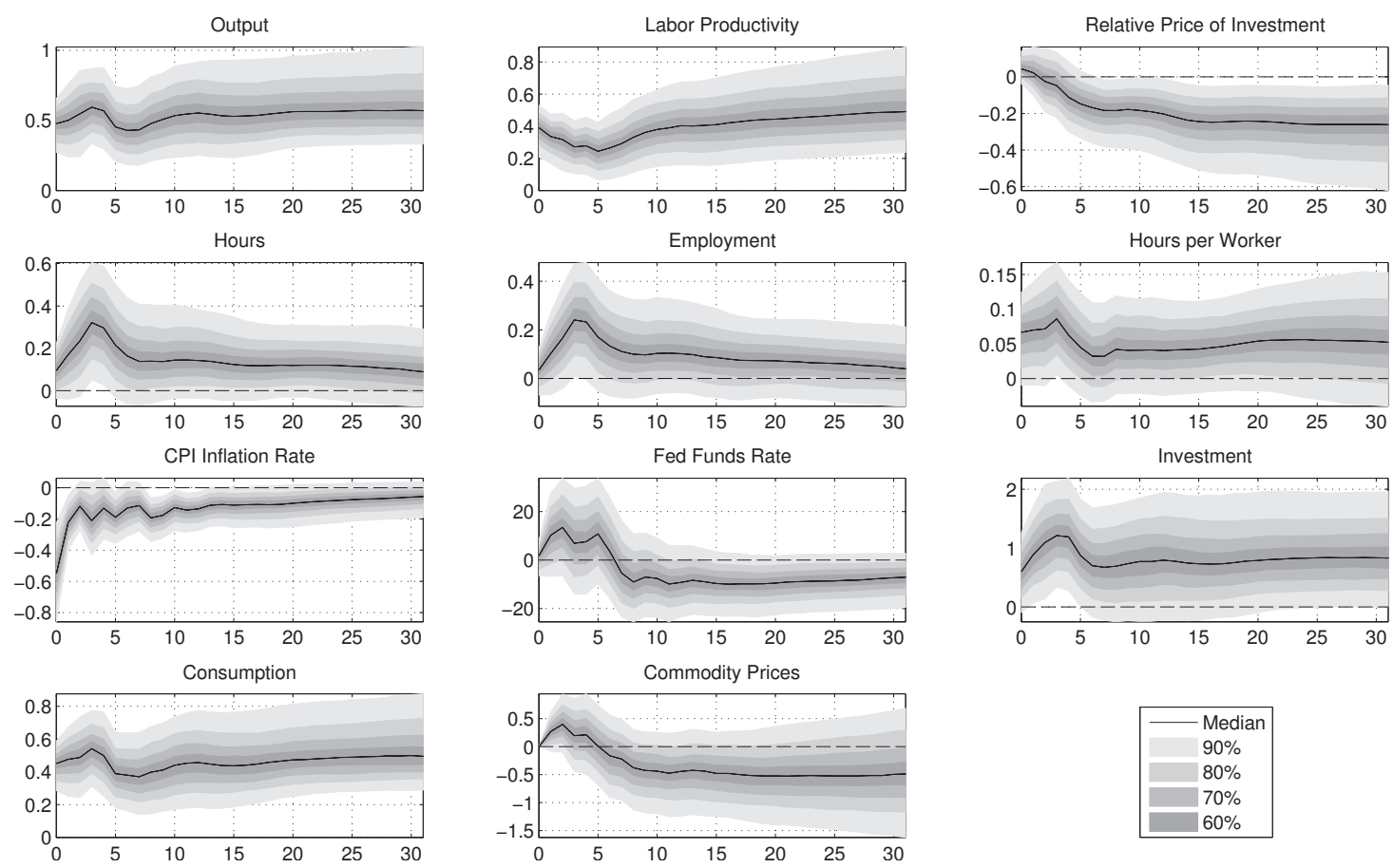

(b) Level Specification

Figure 5: The figure illustrates the impulse responses to a neutral technology shock. 


\section{Trivariate}
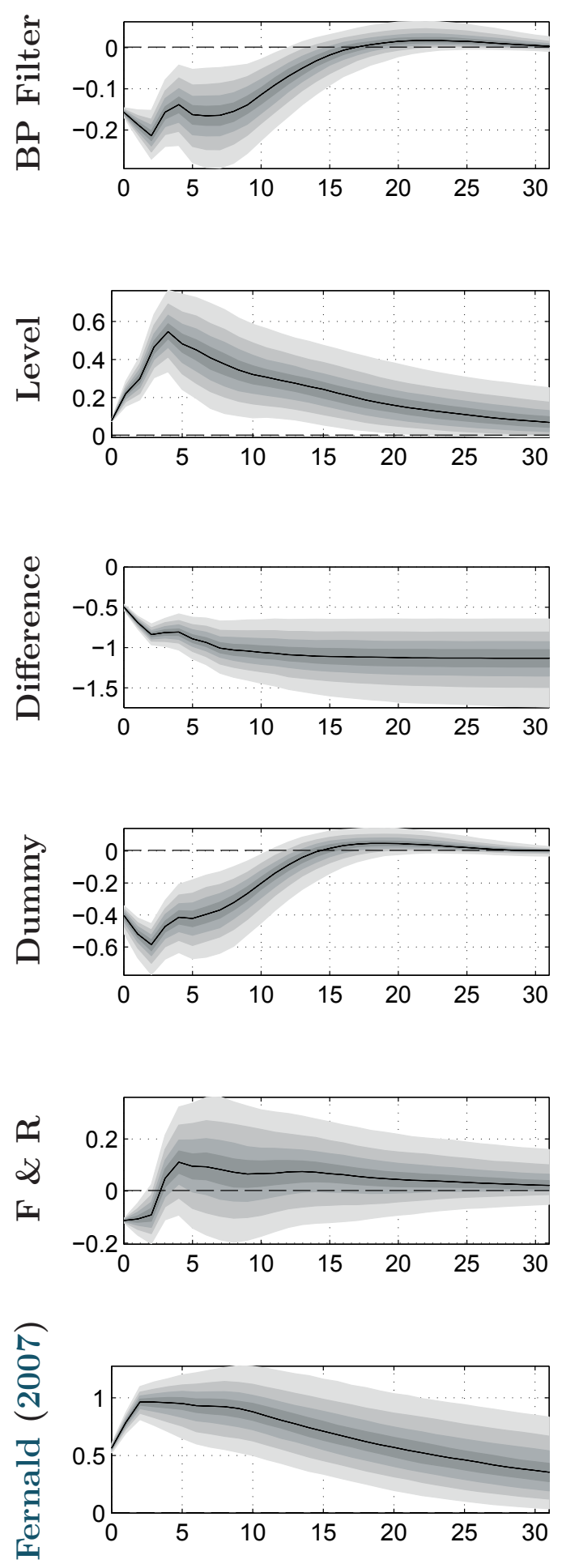

\section{9-variate Model}
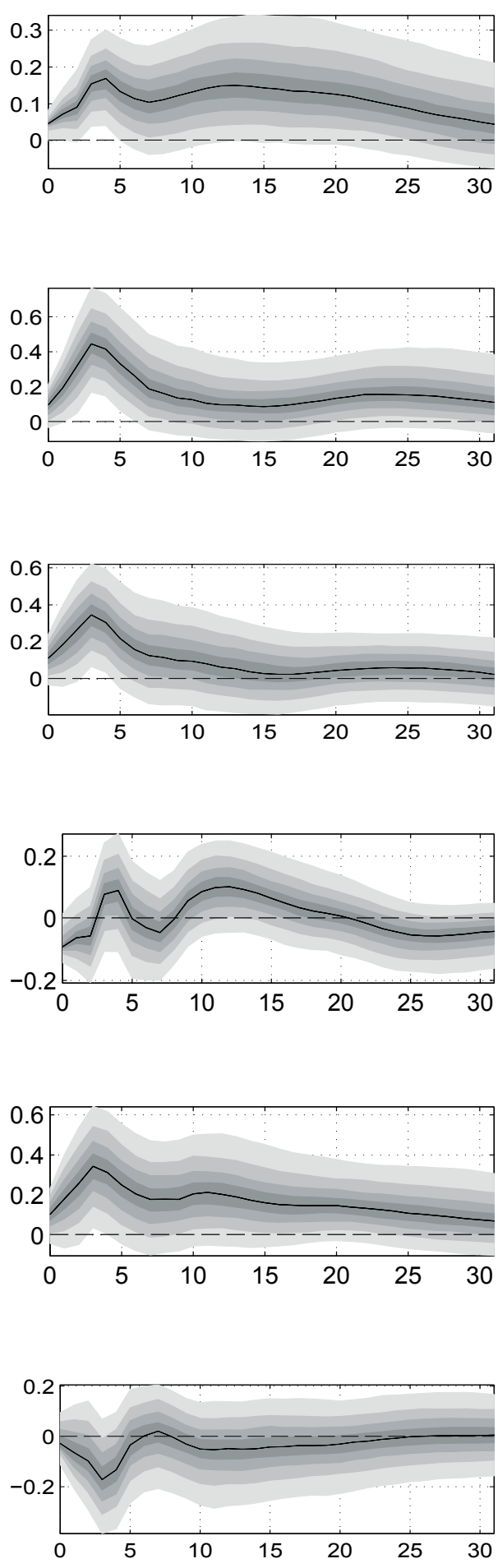

Figure 6: The figure illustrates the low-frequency bias by the means of the per-capita hours response to a neutral technology shock. 

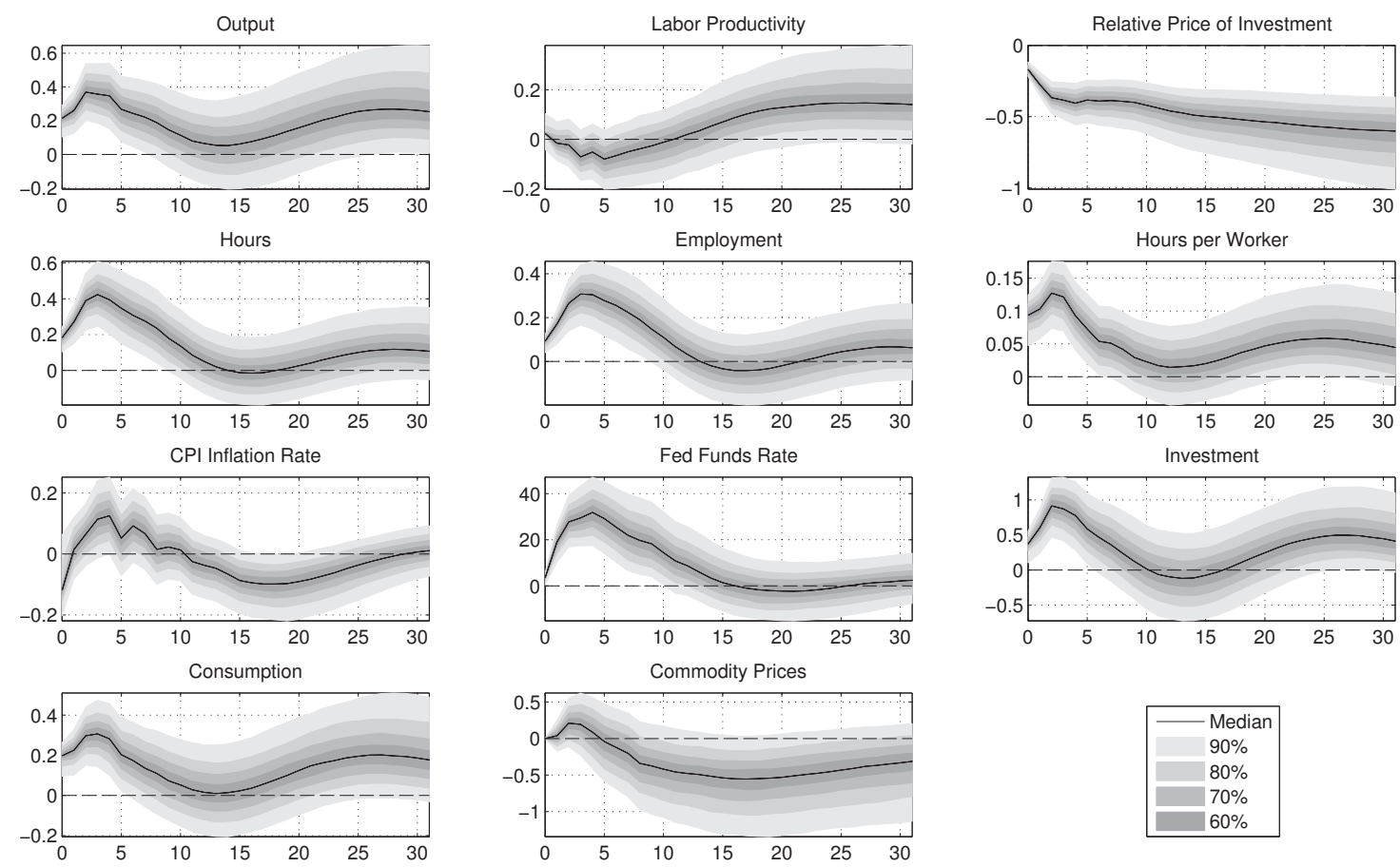

(a) Benchmark Specification
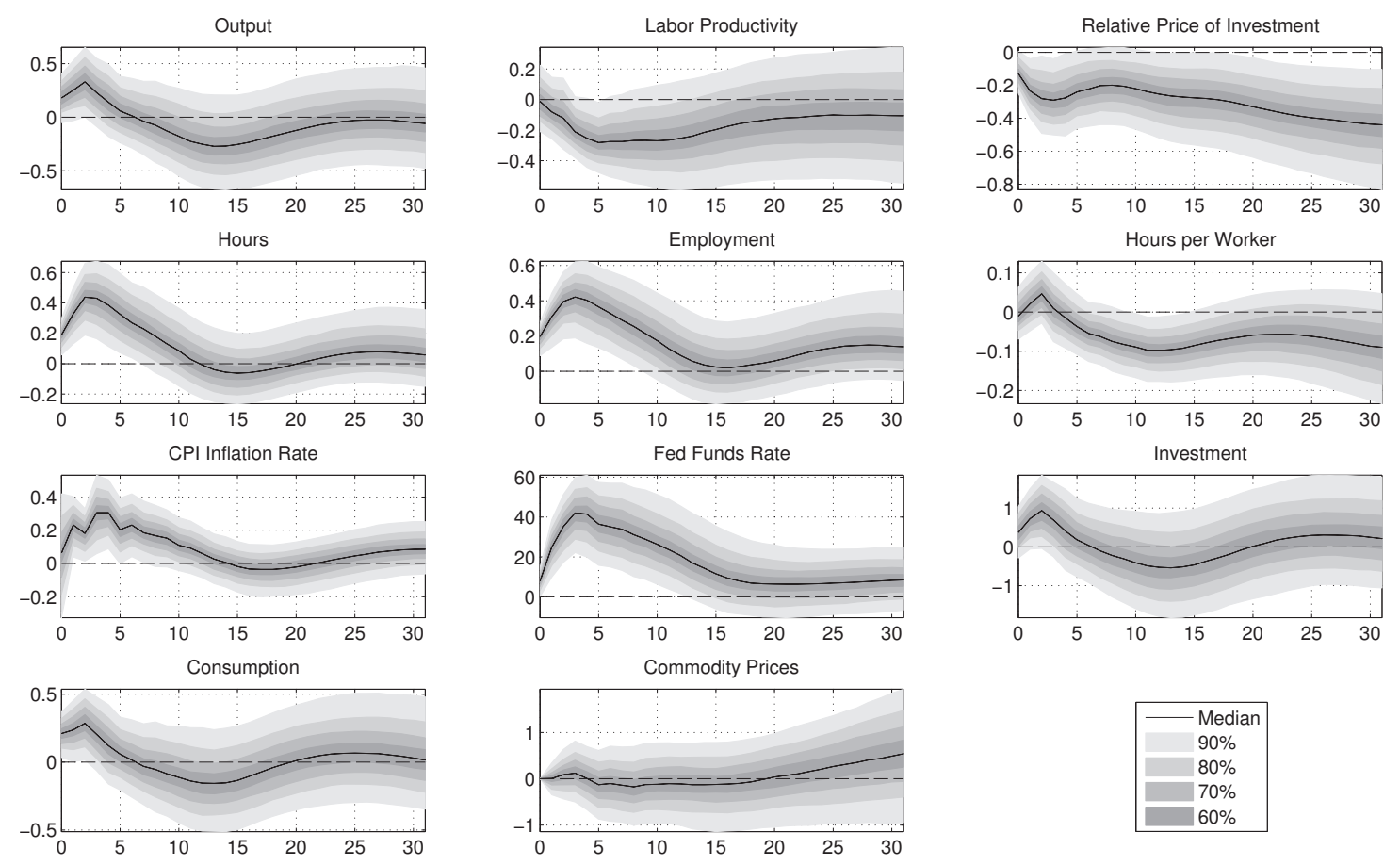

(b) Level Specification

Figure 7: The figure illustrates the impulse responses to an investment-specific technology shock. 


\section{B.4 Counterfactual Exercise}

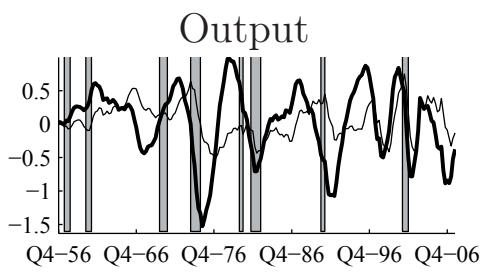

Fed Funds Rate
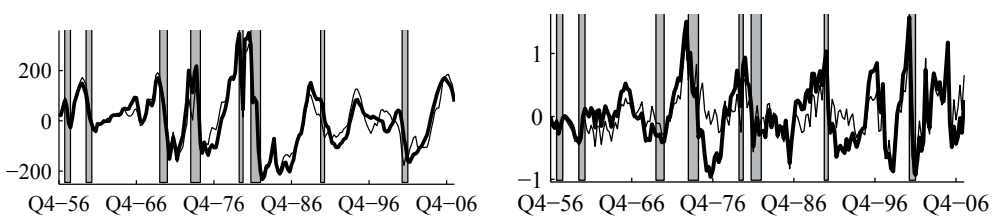

Figure 8: The graphs illustrate the time path of output, the Federal Funds rate, and inflation predicted by commodity price shock (bold line) with the same series predicted by the commodity price shock in the absence of a monetary policy feedback rule (thin line).
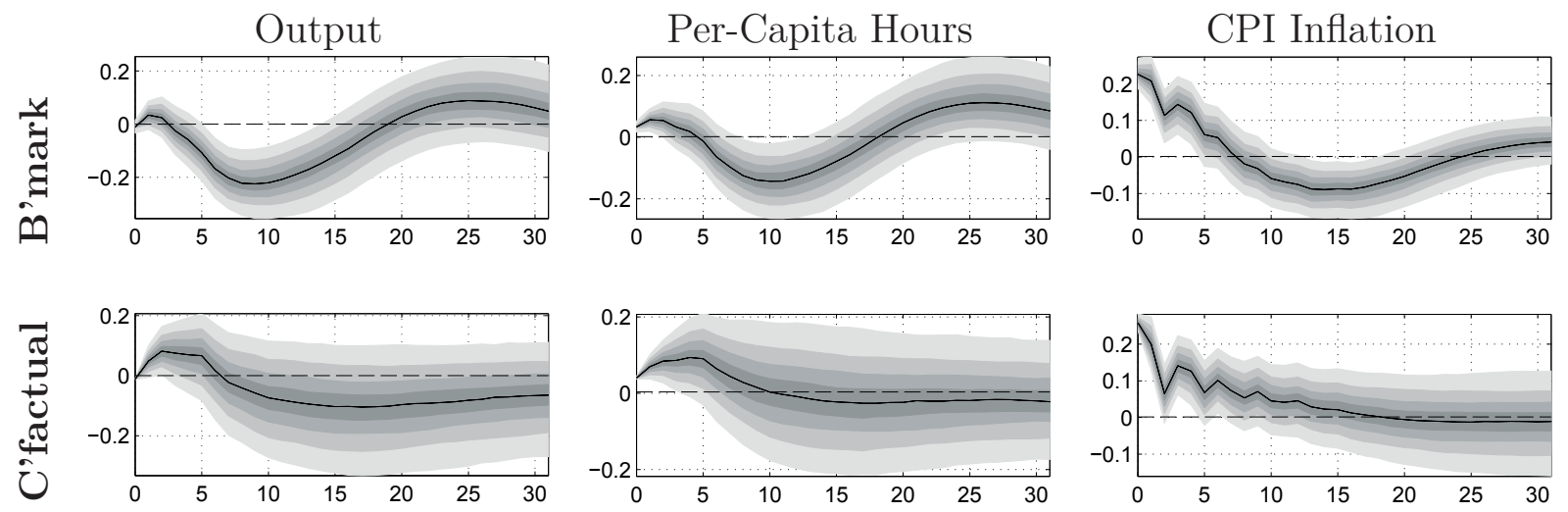

Figure 9: The top panel illustrates the responses of output, per-capita hours, and inflation to the estimated commodity price shock. The bottom panel illustrates the same responses when the Federal Funds rate — counterfactually — is assumed to be constant.
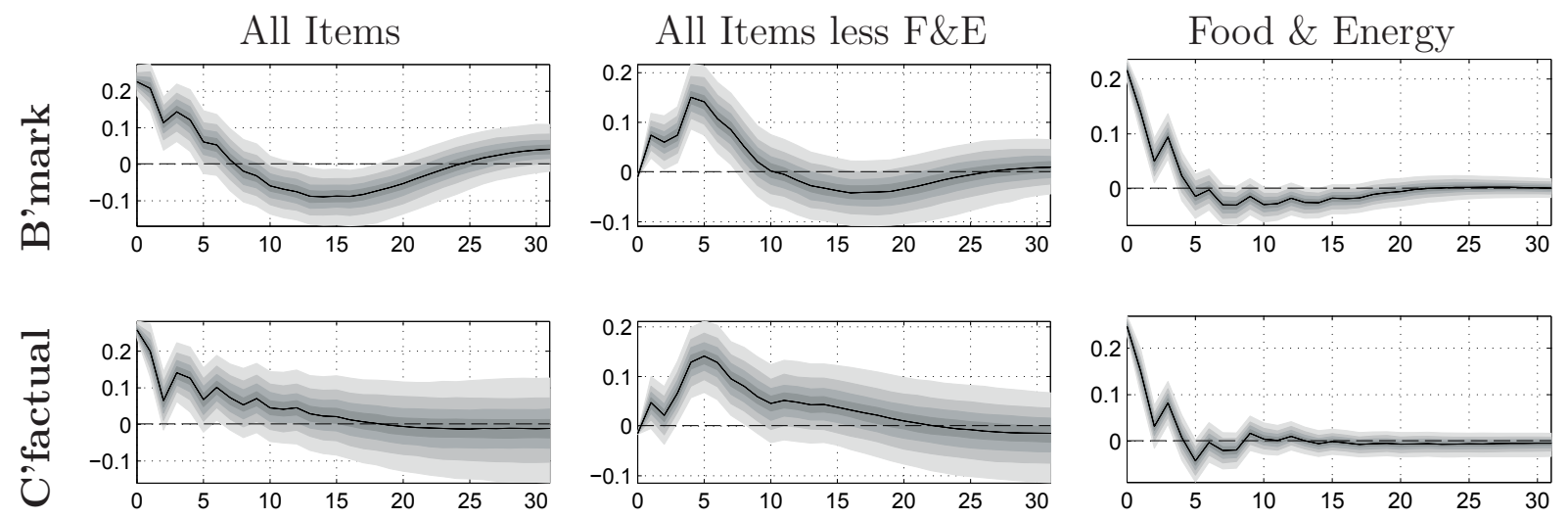

Figure 10: The figure illustrates the impulse responses of three CPI inflation measures to the identified commodity price shock; i.e., the "headline" inflation rate (all items), the "core" inflation rate (all items less food and energy), and the "food and energy" inflation rate. Due to limited data availability, the latter two responses are estimated using a slightly reduced sample period (1958Q2-2007Q4). The CPI "food and energy" is a weighted average of its components, using time varying weights (based on own calculations). All data are taken from FRED. 


\section{B.5 Forecast Error Variance Decomposition}
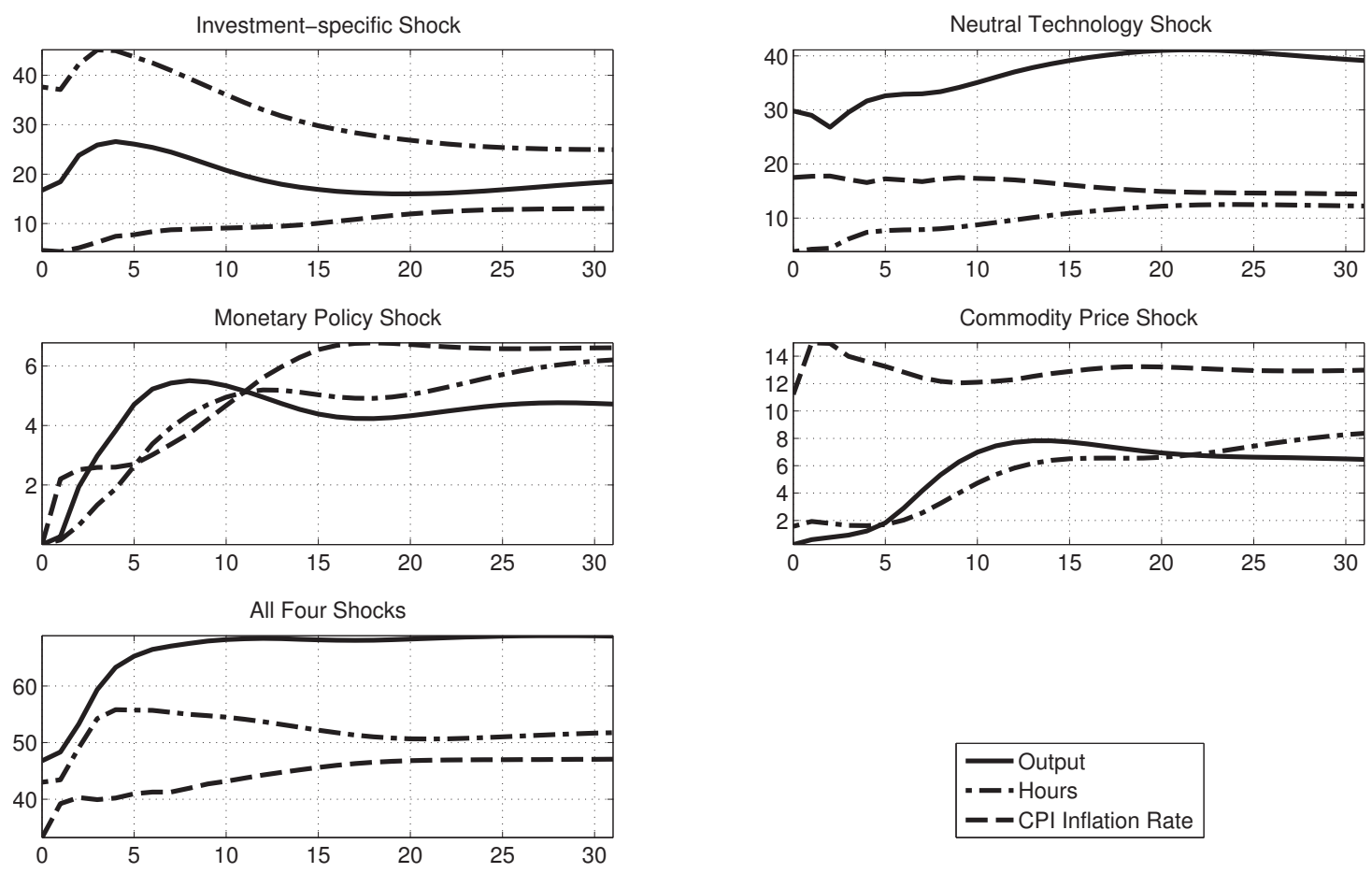

Figure 11: The figure illustrates the forecast error variance decomposition in our benchmark specification.

\section{B.6 Variance Decomposition at the Frequency Domain}
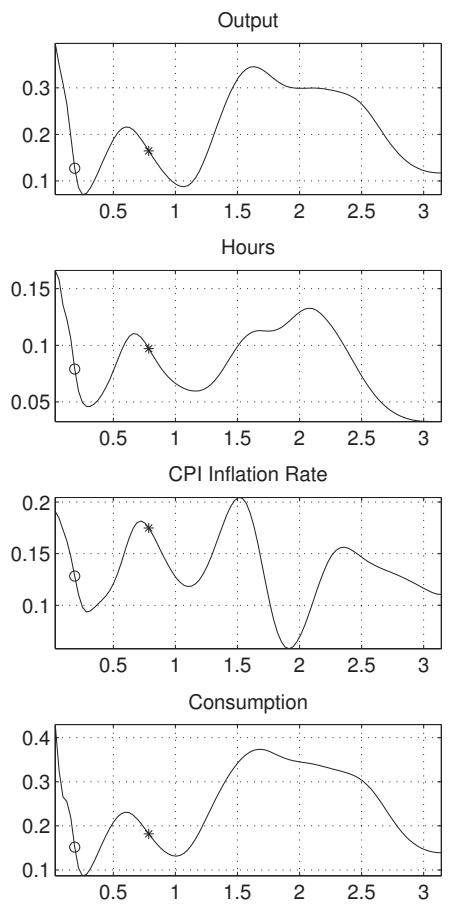
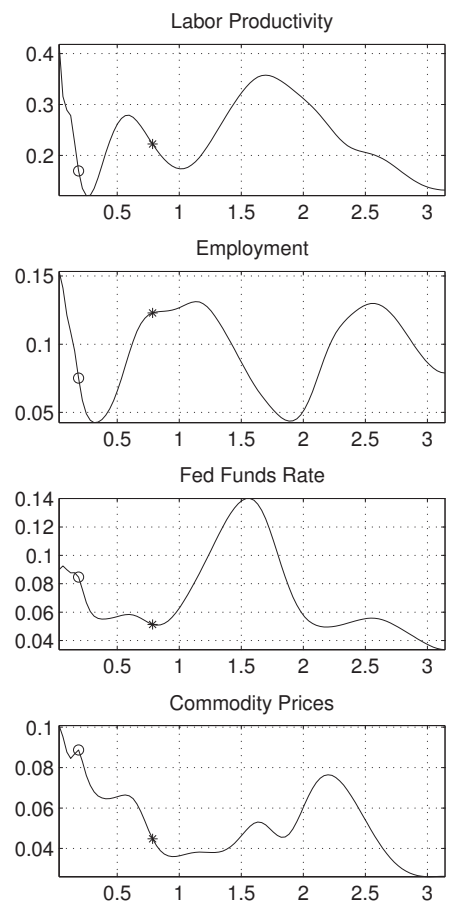
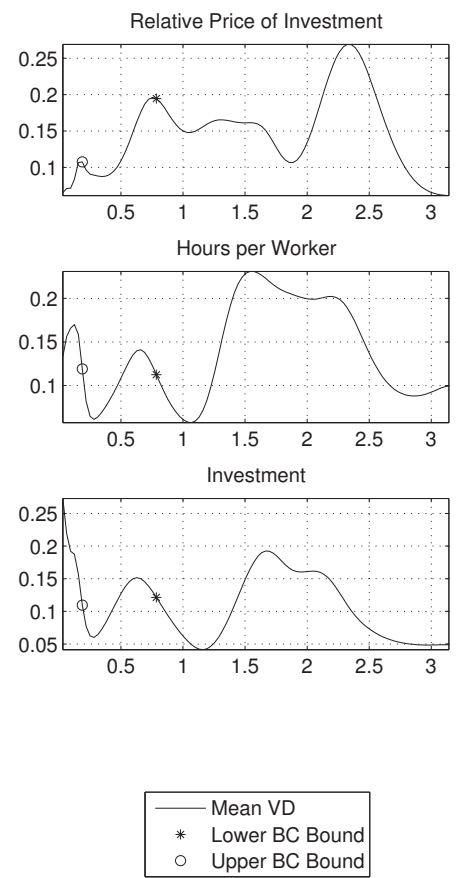

Figure 12: The figure illustrates the explanatory power of neutral technology shocks across the whole spectrum in our benchmark specification. 


\section{B.7 Historical Decomposition of Shocks}

Output
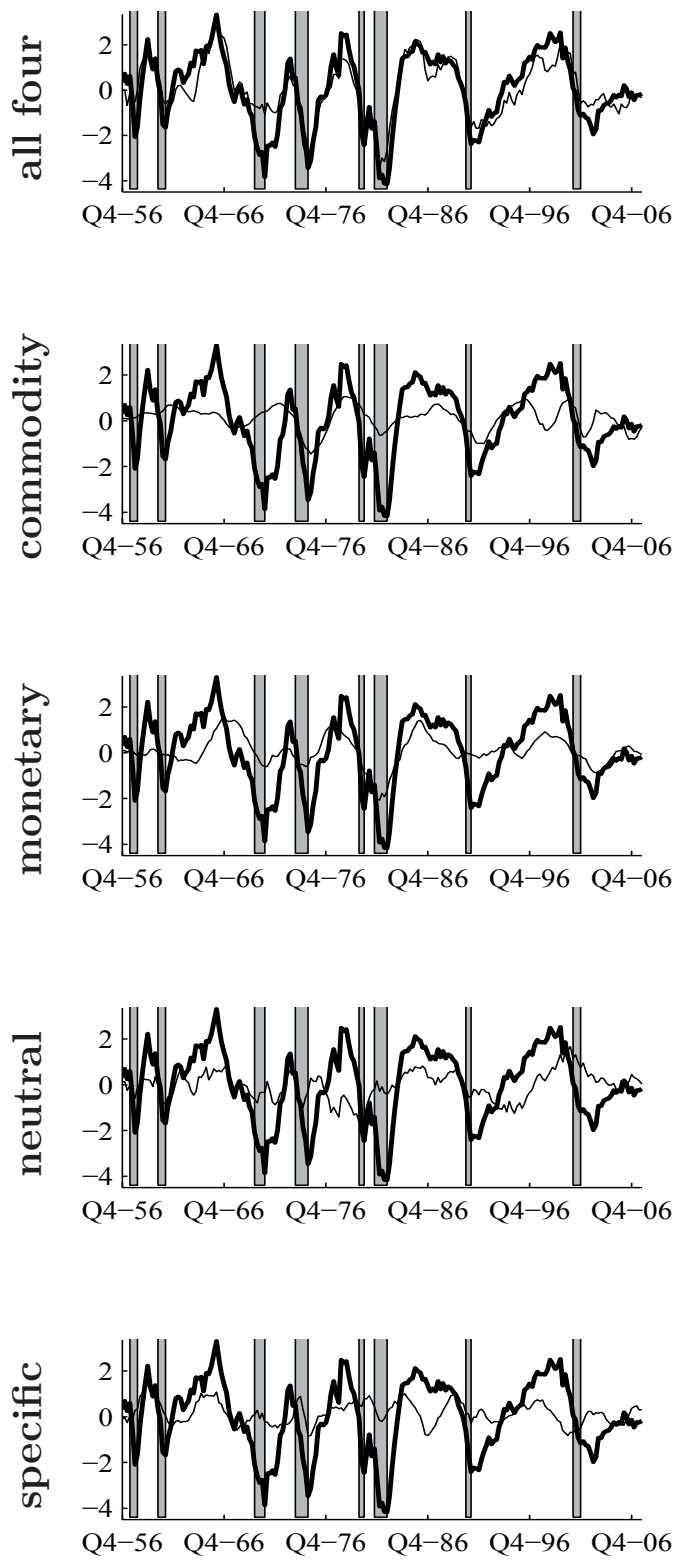

CPI Inflation
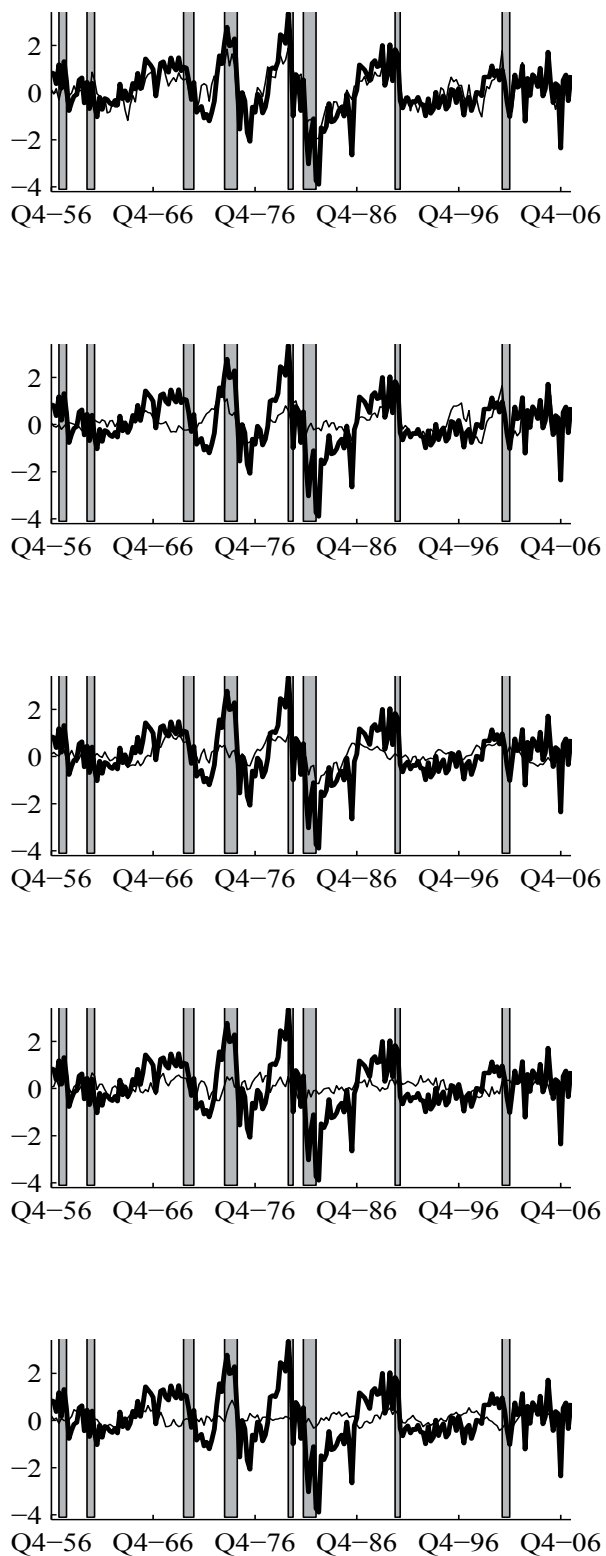

Figure 13: The figure illustrates the historical decomposition of the four identified structural shocks for output and inflation. The bold line represents the bandpass filtered data, the thin line represents the time series predicted by the respective $\operatorname{shock}(\mathrm{s})$. In addition, the counterfactual exercise contrast the output/inflation series predicted by the commodity price shock (bold line) with the output/inflation series predicted by the commodity price shock in the absence of the monetary policy feedback rule (thin line). 


\section{B.8 Commodity Price Index in First Differences}
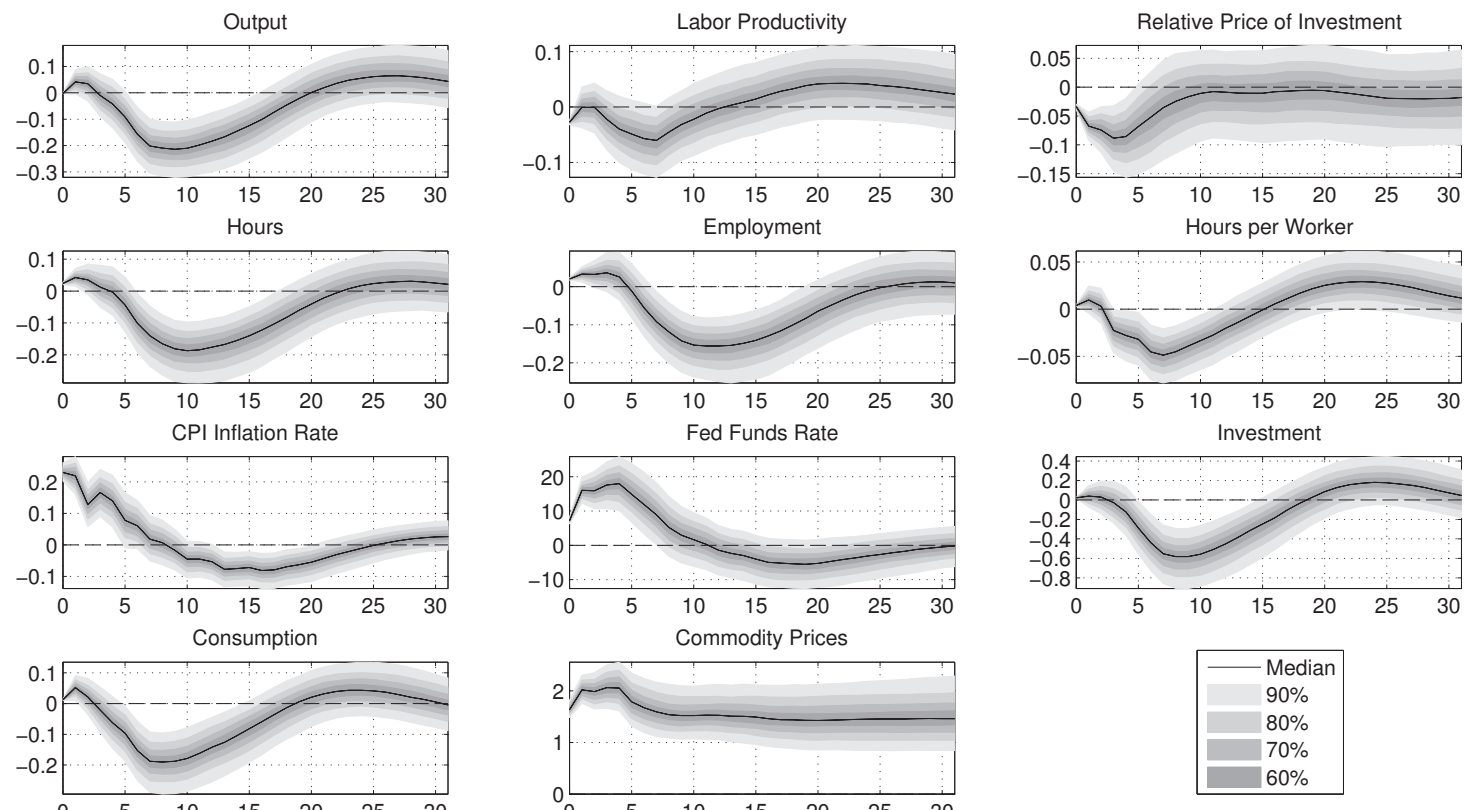

Figure 14: The figure illustrates the impulse responses to a commodity price shock when we first difference the natural logarithm of the commodity price index and then apply the one-sided bandpass filter. 


\section{B.9 Subsample Stability}

\section{Full Sample}
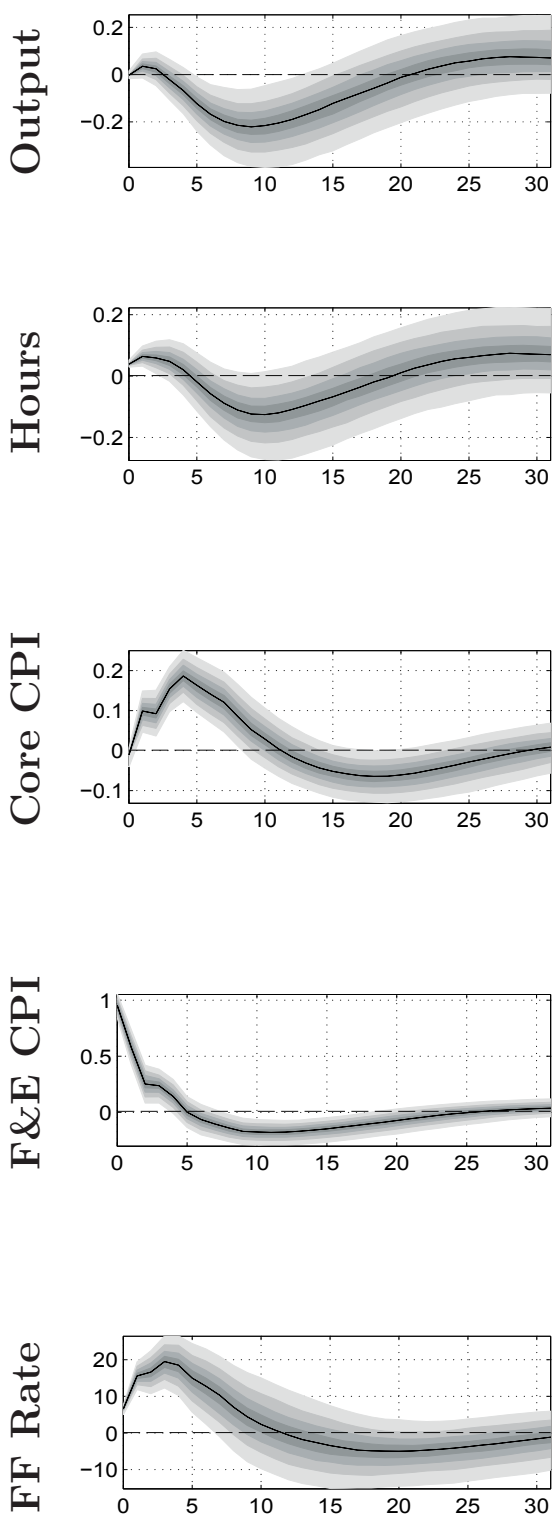

Pre-Volcker
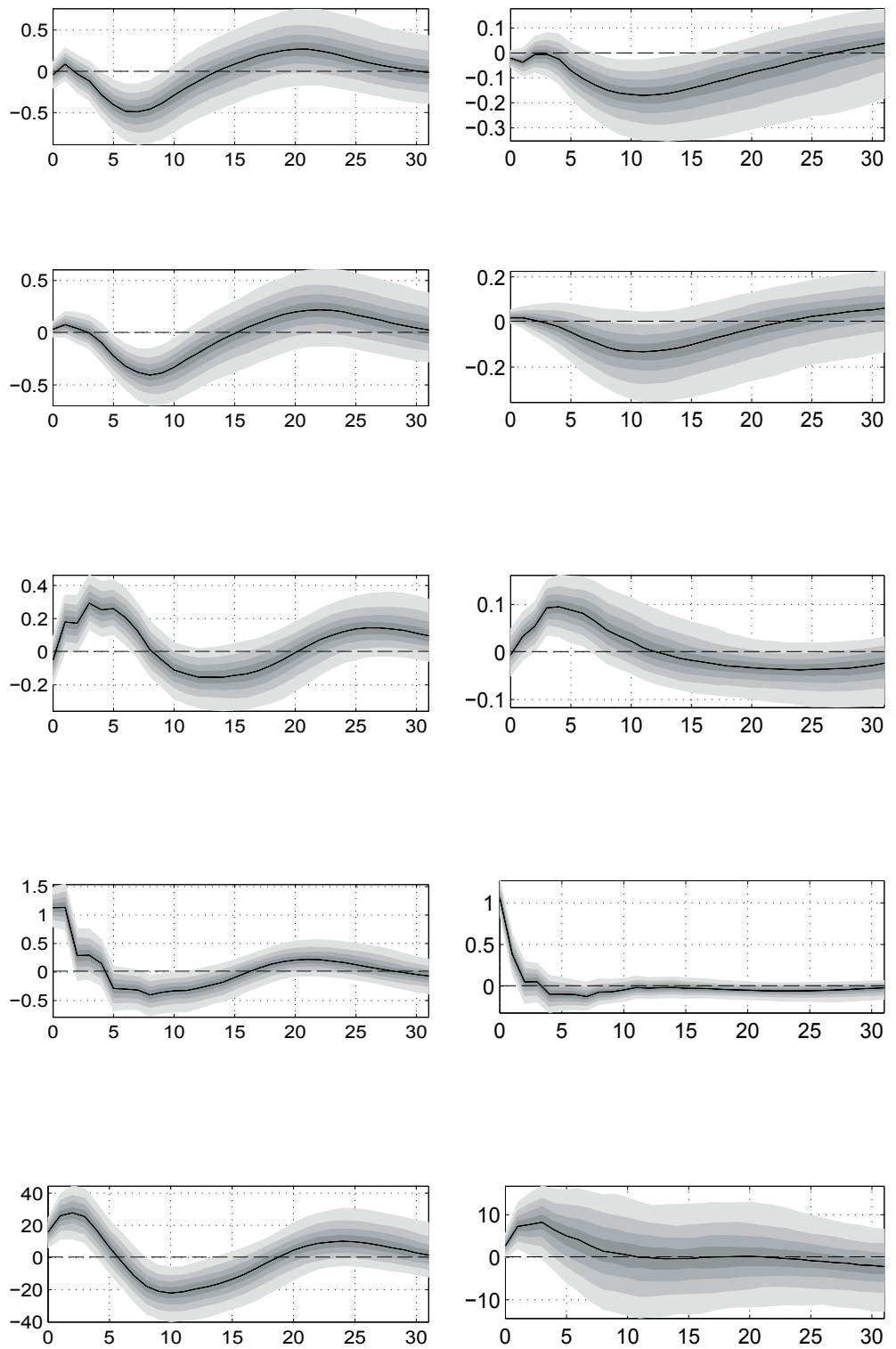

Figure 15: The figure contrasts the impulse responses to a commodity price shock in the "full" sample (1959Q1-2007Q4), the pre-Volcker period (1959Q1-1979Q2), and in the post-Volcker period (1980Q12007Q4). All three models are estimated with three lags $(M=3)$. In order to facilitate comparability across sub-samples, the standard deviation of the commodity price shock is normalized to the standard deviation over the full sample. 


\section{B.10 External Demand}
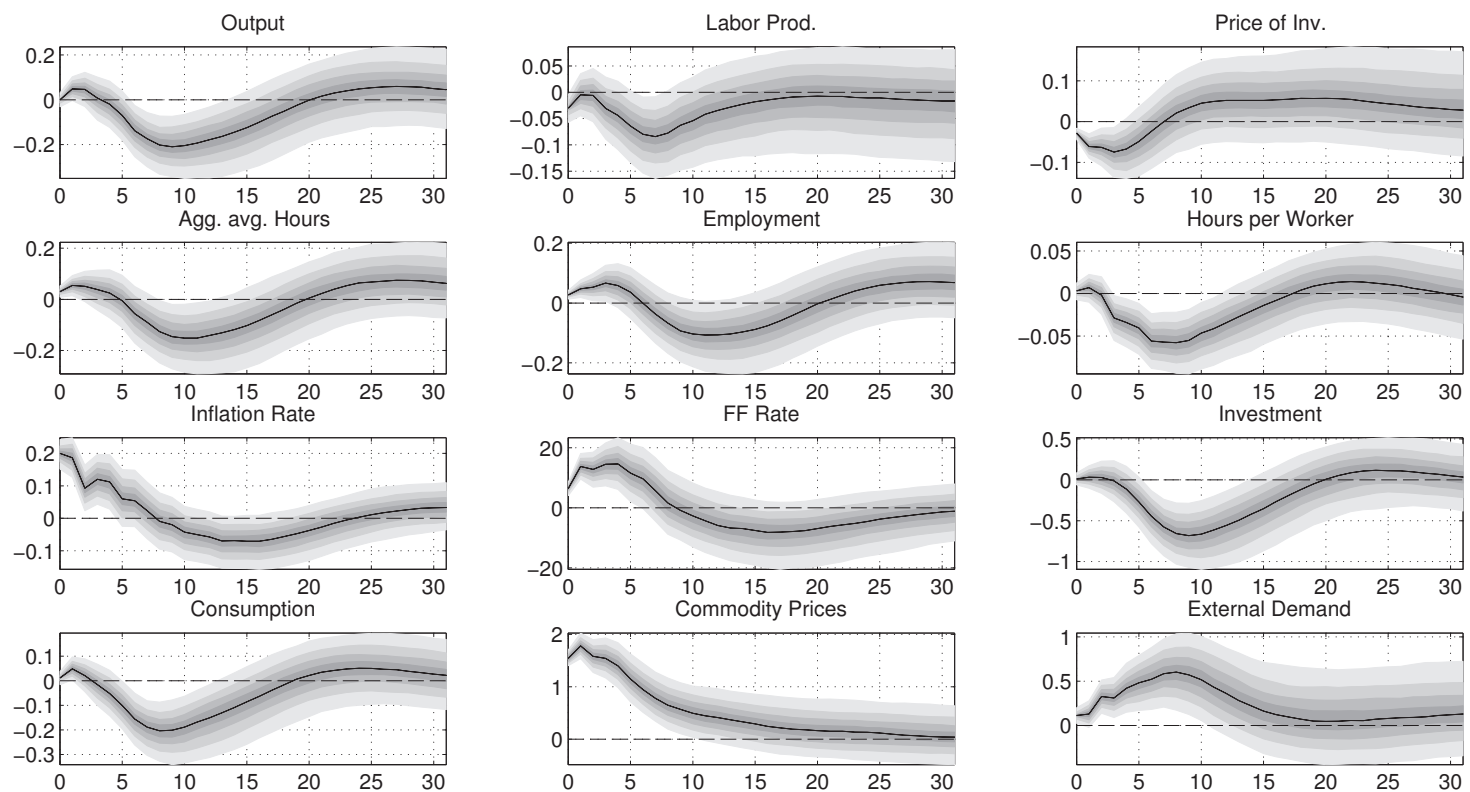

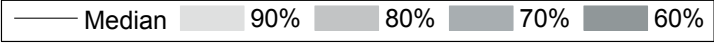

(a) Commodity Price Shock
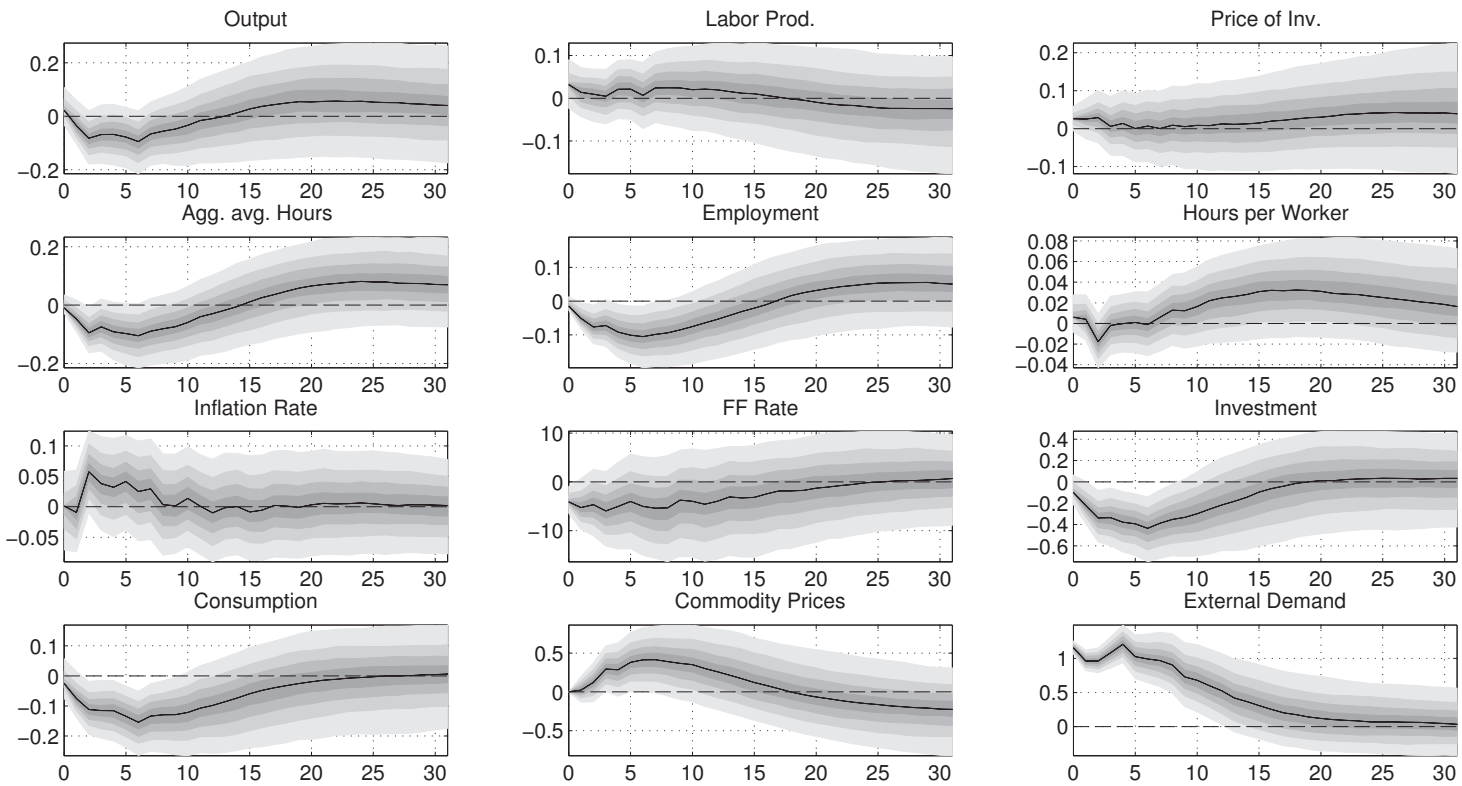

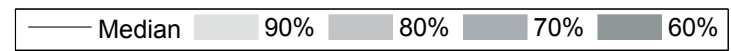

(b) External Demand Shock

Figure 16: The figure illustrates the impulse responses when we include external demand shocks. 


\section{B.11 Commodity Prices: Relaxed Exogeneity Assumption}
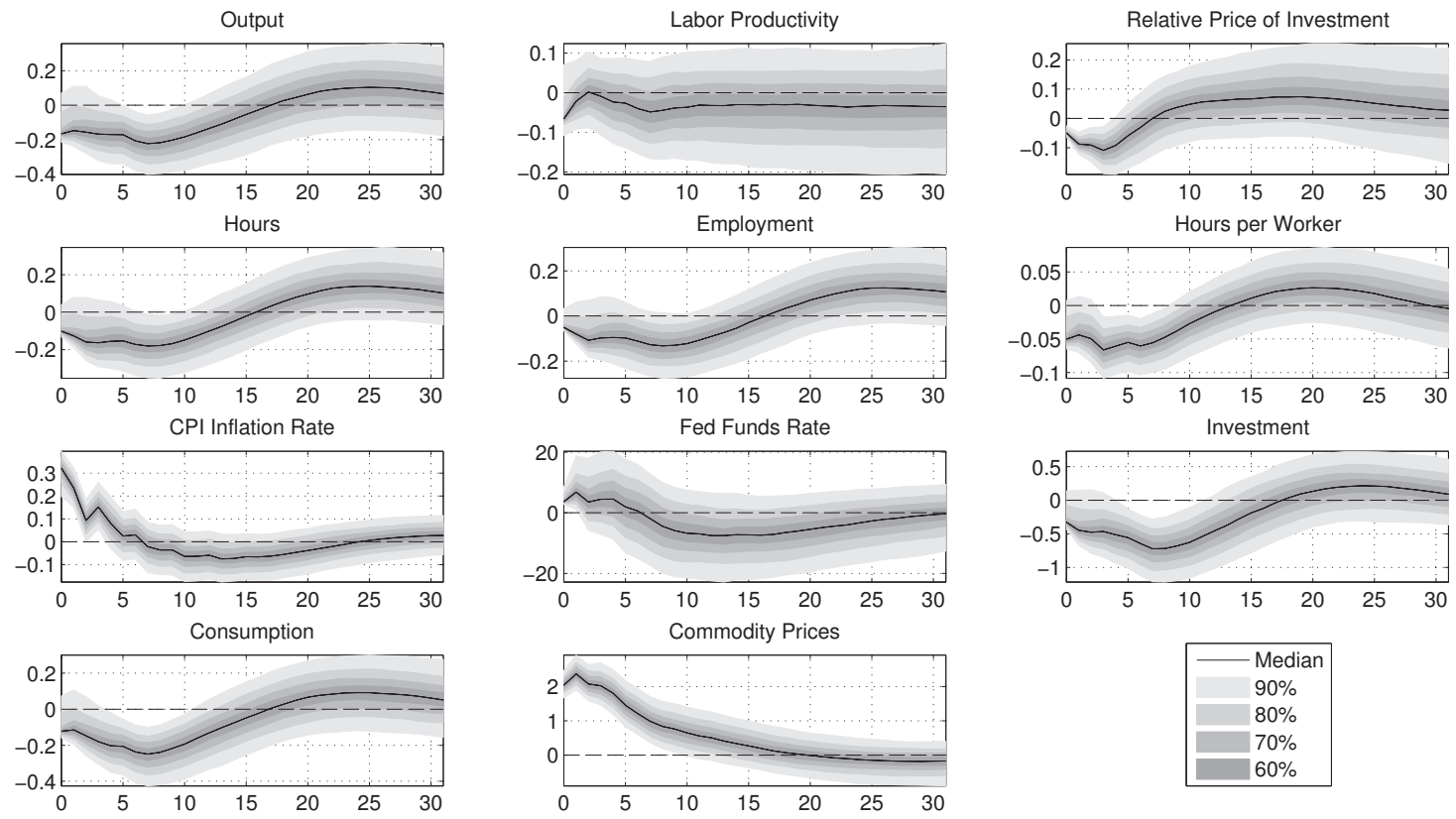

Figure 17: The figure illustrates the impulse responses to a commodity price shock when commodity prices may depend on the current values of labor productivity and per-capita hours.

\section{B.12 Thomson Reuters Continuous Commodity Index}
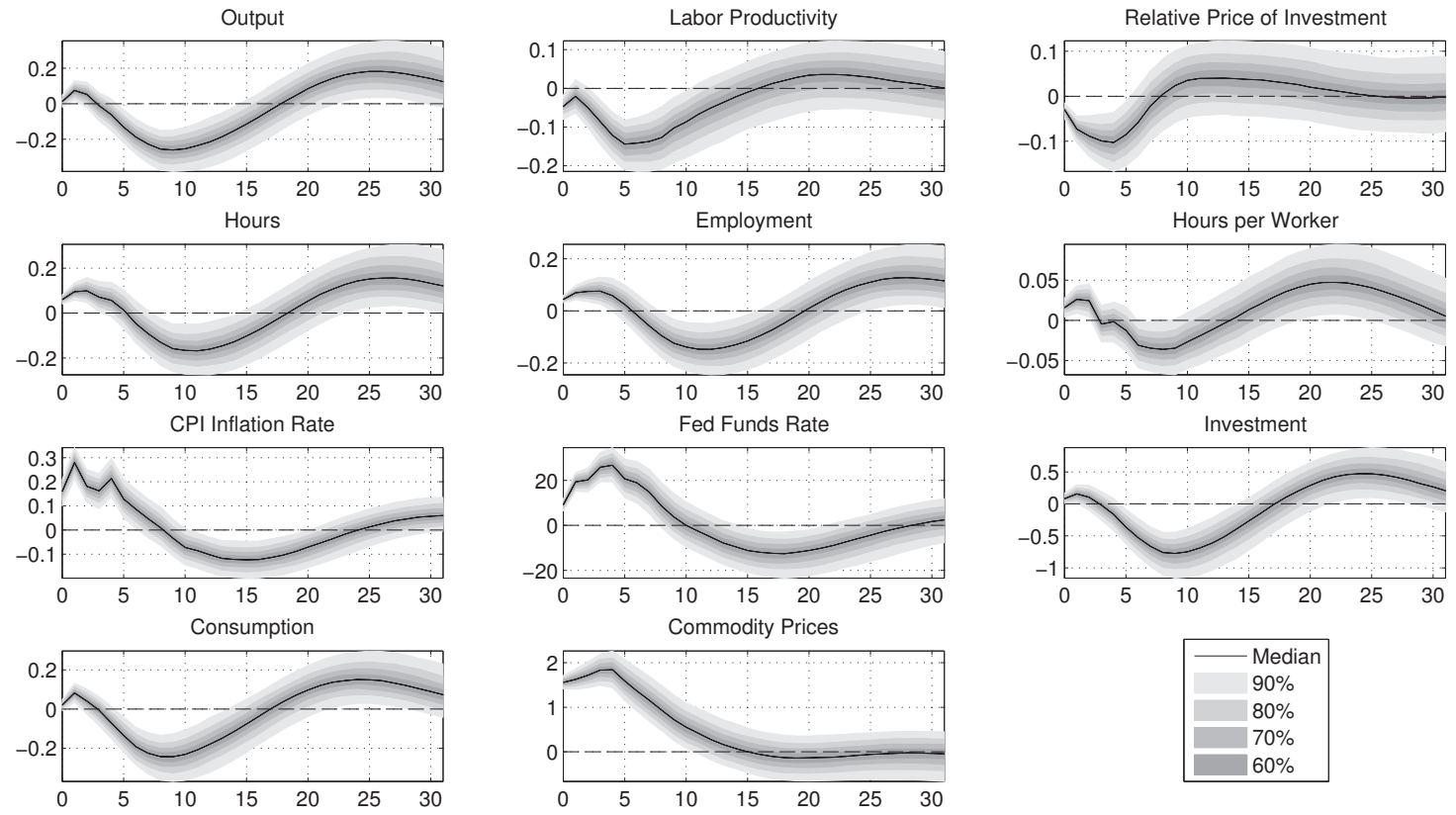

Figure 18: The figure illustrates the impulse responses to a commodity price shock when commodity prices are represented by the Thomson Reuters Continuous Commodity Index. 


\section{Swiss National Bank Working Papers published since 2004:}

2004-1 Samuel Reynard: Financial Market Participation and the Apparent Instability of Money Demand

2004-2 Urs W. Birchler and Diana Hancock: What Does the Yield on Subordinated Bank Debt Measure?

2005-1 Hasan Bakhshi, Hashmat Khan and Barbara Rudolf: The Phillips curve under state-dependent pricing

2005-2 Andreas M. Fischer: On the Inadequacy of Newswire Reports for Empirical Research on Foreign Exchange Interventions

2006-1 Andreas M. Fischer: Measuring Income Elasticity for Swiss Money Demand: What do the Cantons say about Financial Innovation?

2006-2 Charlotte Christiansen and Angelo Ranaldo: Realized Bond-Stock Correlation: Macroeconomic Announcement Effects

2006-3 Martin Brown and Christian Zehnder: Credit Reporting, Relationship Banking, and Loan Repayment

2006-4 Hansjörg Lehmann and Michael Manz: The Exposure of Swiss Banks to Macroeconomic Shocks - an Empirical Investigation

2006-5 Katrin Assenmacher-Wesche and Stefan Gerlach: Money Growth, Output Gaps and Inflation at Low and High Frequency: Spectral Estimates for Switzerland

2006-6 Marlene Amstad and Andreas M. Fischer: Time-Varying Pass-Through from Import Prices to Consumer Prices: Evidence from an Event Study with Real-Time Data

2006-7 Samuel Reynard: Money and the Great Disinflation

2006-8 Urs W. Birchler and Matteo Facchinetti: Can bank supervisors rely on market data? A critical assessment from a Swiss perspective

2006-9 Petra Gerlach-Kristen: A Two-Pillar Phillips Curve for Switzerland

2006-10 Kevin J. Fox and Mathias Zurlinden: On Understanding Sources of Growth and Output Gaps for Switzerland

2006-11 Angelo Ranaldo: Intraday Market Dynamics Around Public Information Arrivals

2007-1 Andreas M. Fischer, Gulzina Isakova and Ulan Termechikov: Do FX traders in Bishkek have similar perceptions to their London colleagues? Survey evidence of market practitioners' views 
2007-2 Ibrahim Chowdhury and Andreas Schabert: Federal Reserve Policy viewed through a Money Supply Lens

2007-3 Angelo Ranaldo: Segmentation and Time-of-Day Patterns in Foreign Exchange Markets

2007-4 Jürg M. Blum: Why ‘Basel II' May Need a Leverage Ratio Restriction

2007-5 Samuel Reynard: Maintaining Low Inflation: Money, Interest Rates, and Policy Stance

2007-6 Rina Rosenblatt-Wisch: Loss Aversion in Aggregate Macroeconomic Time Series

2007-7 Martin Brown, Maria Rueda Maurer, Tamara Pak and Nurlanbek Tynaev: Banking Sector Reform and Interest Rates in Transition Economies: Bank-Level Evidence from Kyrgyzstan

2007-8 Hans-Jürg Büttler: An Orthogonal Polynomial Approach to Estimate the Term Structure of Interest Rates

2007-9 Raphael Auer: The Colonial Origins Of Comparative Development: Comment. A Solution to the Settler Mortality Debate

2007-10 Franziska Bignasca and Enzo Rossi: Applying the Hirose-Kamada filter to Swiss data: Output gap and exchange rate pass-through estimates

2007-11 Angelo Ranaldo and Enzo Rossi: The reaction of asset markets to Swiss National Bank communication

2007-12 Lukas Burkhard and Andreas M. Fischer: Communicating Policy Options at the Zero Bound

2007-13 Katrin Assenmacher-Wesche, Stefan Gerlach, and Toshitaka Sekine: Monetary Factors and Inflation in Japan

2007-14 Jean-Marc Natal and Nicolas Stoffels: Globalization, markups and the natural rate of interest

2007-15 Martin Brown, Tullio Jappelli and Marco Pagano: Information Sharing and Credit: Firm-Level Evidence from Transition Countries

2007-16 Andreas M. Fischer, Matthias Lutz and Manuel Wälti: Who Prices Locally? Survey Evidence of Swiss Exporters

2007-17 Angelo Ranaldo and Paul Söderlind: Safe Haven Currencies 
2008-1 Martin Brown and Christian Zehnder: The Emergence of Information Sharing in Credit Markets

2008-2 Yvan Lengwiler and Carlos Lenz: Intelligible Factors for the Yield Curve

2008-3 Katrin Assenmacher-Wesche and M. Hashem Pesaran: Forecasting the Swiss Economy Using VECX* Models: An Exercise in Forecast Combination Across Models and Observation Windows

2008-4 Maria Clara Rueda Maurer: Foreign bank entry, institutional development and credit access: firm-level evidence from 22 transition countries

2008-5 Marlene Amstad and Andreas M. Fischer: Are Weekly Inflation Forecasts Informative?

2008-6 Raphael Auer and Thomas Chaney: Cost Pass Through in a Competitive Model of Pricing-to-Market

2008-7 Martin Brown, Armin Falk and Ernst Fehr: Competition and Relational Contracts: The Role of Unemployment as a Disciplinary Device

2008-8 Raphael Auer: The Colonial and Geographic Origins of Comparative Development

2008-9 Andreas M. Fischer and Angelo Ranaldo: Does FOMC News Increase Global FX Trading?

2008-10 Charlotte Christiansen and Angelo Ranaldo: Extreme Coexceedances in New EU Member States' Stock Markets

2008-11 Barbara Rudolf and Mathias Zurlinden: Measuring capital stocks and capital services in Switzerland

2008-12 Philip Sauré: How to Use Industrial Policy to Sustain Trade Agreements

2008-13 Thomas Bolli and Mathias Zurlinden: Measuring growth of labour quality and the quality-adjusted unemployment rate in Switzerland

2008-14 Samuel Reynard: What Drives the Swiss Franc?

2008-15 Daniel Kaufmann: Price-Setting Behaviour in Switzerland - Evidence from CPI Micro Data

2008-16 Katrin Assenmacher-Wesche and Stefan Gerlach: Financial Structure and the Impact of Monetary Policy on Asset Prices

2008-17 Ernst Fehr, Martin Brown and Christian Zehnder: On Reputation: A Microfoundation of Contract Enforcement and Price Rigidity 
2008-18 Raphael Auer and Andreas M. Fischer: The Effect of Low-Wage Import Competition on U.S. Inflationary Pressure

2008-19 Christian Beer, Steven Ongena and Marcel Peter: Borrowing in Foreign Currency: Austrian Households as Carry Traders

2009-1 Thomas Bolli and Mathias Zurlinden: Measurement of labor quality growth caused by unobservable characteristics

2009-2 Martin Brown, Steven Ongena and Pinar Yesin: Foreign Currency Borrowing by Small Firms

2009-3 Matteo Bonato, Massimiliano Caporin and Angelo Ranaldo: Forecasting realized (co)variances with a block structure Wishart autoregressive model

2009-4 Paul Söderlind: Inflation Risk Premia and Survey Evidence on Macroeconomic Uncertainty

2009-5 Christian Hott: Explaining House Price Fluctuations

2009-6 Sarah M. Lein and Eva Köberl: Capacity Utilisation, Constraints and Price Adjustments under the Microscope

2009-7 Philipp Haene and Andy Sturm: Optimal Central Counterparty Risk Management

2009-8 Christian Hott: Banks and Real Estate Prices

2009-9 Terhi Jokipii and Alistair Milne: Bank Capital Buffer and Risk Adjustment Decisions

2009-10 Philip Sauré: Bounded Love of Variety and Patterns of Trade

2009-11 Nicole Allenspach: Banking and Transparency: Is More Information Always Better?

2009-12 Philip Sauré and Hosny Zoabi: Effects of Trade on Female Labor Force Participation

2009-13 Barbara Rudolf and Mathias Zurlinden: Productivity and economic growth in Switzerland 1991-2005

2009-14 Sébastien Kraenzlin and Martin Schlegel: Bidding Behavior in the SNB's Repo Auctions

2009-15 Martin Schlegel and Sébastien Kraenzlin: Demand for Reserves and the Central Bank's Management of Interest Rates

2009-16 Carlos Lenz and Marcel Savioz: Monetary determinants of the Swiss franc 
2010-1 Charlotte Christiansen, Angelo Ranaldo and Paul Söderlind: The Time-Varying Systematic Risk of Carry Trade Strategies

2010-2 Daniel Kaufmann: The Timing of Price Changes and the Role of Heterogeneity

2010-3 Loriano Mancini, Angelo Ranaldo and Jan Wrampelmeyer: Liquidity in the Foreign Exchange Market: Measurement, Commonality, and Risk Premiums

2010-4 Samuel Reynard and Andreas Schabert: Modeling Monetary Policy

2010-5 Pierre Monnin and Terhi Jokipii: The Impact of Banking Sector Stability on the Real Economy

2010-6 Sébastien Kraenzlin and Thomas Nellen: Daytime is money

2010-7 Philip Sauré: Overreporting Oil Reserves

2010-8 Elizabeth Steiner: Estimating a stock-flow model for the Swiss housing market

2010-9 Martin Brown, Steven Ongena, Alexander Popov, and Pinar Yesin: Who Needs Credit and Who Gets Credit in Eastern Europe?

2010-10 Jean-Pierre Danthine and André Kurmann: The Business Cycle Implications of Reciprocity in Labor Relations

2010-11 Thomas Nitschka: Momentum in stock market returns: Implications for risk premia on foreign currencies

2010-12 Petra Gerlach-Kristen and Barbara Rudolf: Macroeconomic and interest rate volatility under alternative monetary operating procedures

2010-13 Raphael Auer: Consumer Heterogeneity and the Impact of Trade Liberalization: How Representative is the Representative Agent Framework?

2010-14 Tommaso Mancini Griffoli and Angelo Ranaldo: Limits to arbitrage during the crisis: funding liquidity constraints and covered interest parity

2010-15 Jean-Marc Natal: Monetary Policy Response to Oil Price Shocks

2010-16 Kathrin Degen and Andreas M. Fischer: Immigration and Swiss House Prices

2010-17 Andreas M. Fischer: Immigration and large banknotes

2010-18 Raphael Auer: Are Imports from Rich Nations Deskilling Emerging Economies? Human Capital and the Dynamic Effects of Trade 
2010-19 Jean-Pierre Danthine and John B. Donaldson: Executive Compensation: A General Equilibrium Perspective

2011-1 Thorsten Beck and Martin Brown: Which Households Use Banks? Evidence from the Transition Economies

2011-2 Martin Brown, Karolin Kirschenmann and Steven Ongena: Foreign Currency Loans Demand or Supply Driven?

2011-3 Victoria Galsband and Thomas Nitschka: Foreign currency returns and systematic risks

2011-4 Francis Breedon and Angelo Ranaldo: Intraday patterns in FX returns and order flow

2011-5 Basil Guggenheim, Sébastien Kraenzlin and Silvio Schumacher: Exploring an uncharted market: Evidence on the unsecured Swiss franc money market

2011-6 Pamela Hall: Is there any evidence of a Greenspan put?

2011-7 Daniel Kaufmann and Sarah Lein: Sectoral Inflation Dynamics, Idiosyncratic Shocks and Monetary Policy

2011-8 Iva Cecchin: Mortgage Rate Pass-Through in Switzerland

2011-9 Raphael A. Auer, Kathrin Degen and Andreas M. Fischer: Low-Wage Import Competition, Inflationary Pressure, and Industry Dynamics in Europe

2011-10 Raphael A. Auer and Philip Sauré: Spatial Competition in Quality, Demand-Induced Innovation, and Schumpeterian Growth

2011-11 Massimiliano Caporin , Angelo Ranaldo and Paolo Santucci de Magistris: On the Predictability of Stock Prices: a Case for High and Low Prices

2011-12 Jürg Mägerle and Thomas Nellen: Interoperability between central counterparties

2011-13 Sylvia Kaufmann: K-state switching models with endogenous transition distributions

2011-14 Sébastien Kraenzlin and Benedikt von Scarpatetti: Bargaining Power in the Repo Market

2012-01 Raphael A. Auer: Exchange Rate Pass-Through, Domestic Competition, and Inflation: Evidence from the 2005/08 Revaluation of the Renminbi

2012-02 Signe Krogstrup, Samuel Reynard and Barbara Sutter: Liquidity Effects of Quantitative Easing on Long-Term Interest Rates 
2012-03 Matteo Bonato, Massimiliano Caporin and Angelo Ranaldo: Risk spillovers in international equity portfolios

2012-04 Thomas Nitschka: Banking sectors' international interconnectedness: Implications for consumption risk sharing in Europe

2012-05 Martin Brown, Steven Ongena and Pinar Yeşin: Information Asymmetry and Foreign Currency Borrowing by Small Firms

2012-06 Philip Sauré and Hosny Zoabi: Retirement Age across Countries: The Role of Occupations

2012-07 Christian Hott and Terhi Jokipii: Housing Bubbles and Interest Rates

2012-08 Romain Baeriswyl and Camille Cornand: Reducing overreaction to central bank's disclosures: theory and experiment

2012-09 Bo E. Honoré, Daniel Kaufmann and Sarah Lein: Asymmetries in Price-Setting Behavior: New Microeconometric Evidence from Switzerland

2012-10 Thomas Nitschka: Global and country-specific business cycle risk in time-varying excess returns on asset markets

2012-11 Raphael A. Auer, Thomas Chaney and Philip Sauré: Quality Pricing-to-Market

2012-12 Sébastien Kraenzlin and Thomas Nellen: Access policy and money market segmentation

2012-13 Andreas Kropf and Philip Sauré: Fixed Costs per Shipment

2012-14 Raphael A. Auer and Raphael S. Schoenle: Market Structure and Exchange Rate Pass-Through

2012-15 Raphael A. Auer: What Drives Target2 Balances? Evidence From a Panel Analysis

2012-16 Katja Drechsel and Rolf Scheufele: Bottom-up or Direct? Forecasting German GDP in a Data-rich Environment

2013-01 Andreas Kettemann and Signe Krogstrup: Portfolio balance effects of the SNB's bond purchase program

2013-02 Nicole Aregger, Martin Brown and Enzo Rossi: Transaction Taxes, Capital Gains Taxes and House Prices

2013-03 Simone Meier: Financial Globalization and Monetary Transmission 
2013-04 Christian Grisse and Thomas Nitschka: On financial risk and the safe haven characteristics of Swiss franc exchange rates

2013-05 Matthias Gubler and Matthias S. Hertweck: Commodity Price Shocks and the Business Cycle: Structural Evidence for the U.S. 
Swiss National Bank Working Papers are also available at www.snb.ch, section Publications/Research Subscriptions or individual issues can be ordered at Swiss National Bank, Fraumünsterstrasse 8, CH-8022 Zurich, fax +41 4463181 14, E-mail library@snb.ch 
